\title{
When girls' lives matter: Ending forced and early marriage in Cameroon
}

Sajeda Amin

Population Council

Andrea Lynch

Follow this and additional works at: https://knowledgecommons.popcouncil.org/departments_sbsr-pgy

Part of the Demography, Population, and Ecology Commons, Domestic and Intimate Partner Violence Commons, Family, Life Course, and Society Commons, Gender and Sexuality Commons, Gender Equity in Education Commons, International Public Health Commons, Maternal and Child Health Commons, and the Women's Health Commons How does access to this work benefit you? Let us know!

\section{Recommended Citation}

Amin, Sajeda and Andrea Lynch. 2011. "When girls' lives matter: Ending forced and early marriage in Cameroon," Quality/Calidad/Qualité no. 20. New York: Population Council. 
When Girls' Lives Matter:

Ending Forced and Early

Marriage in Cameroon

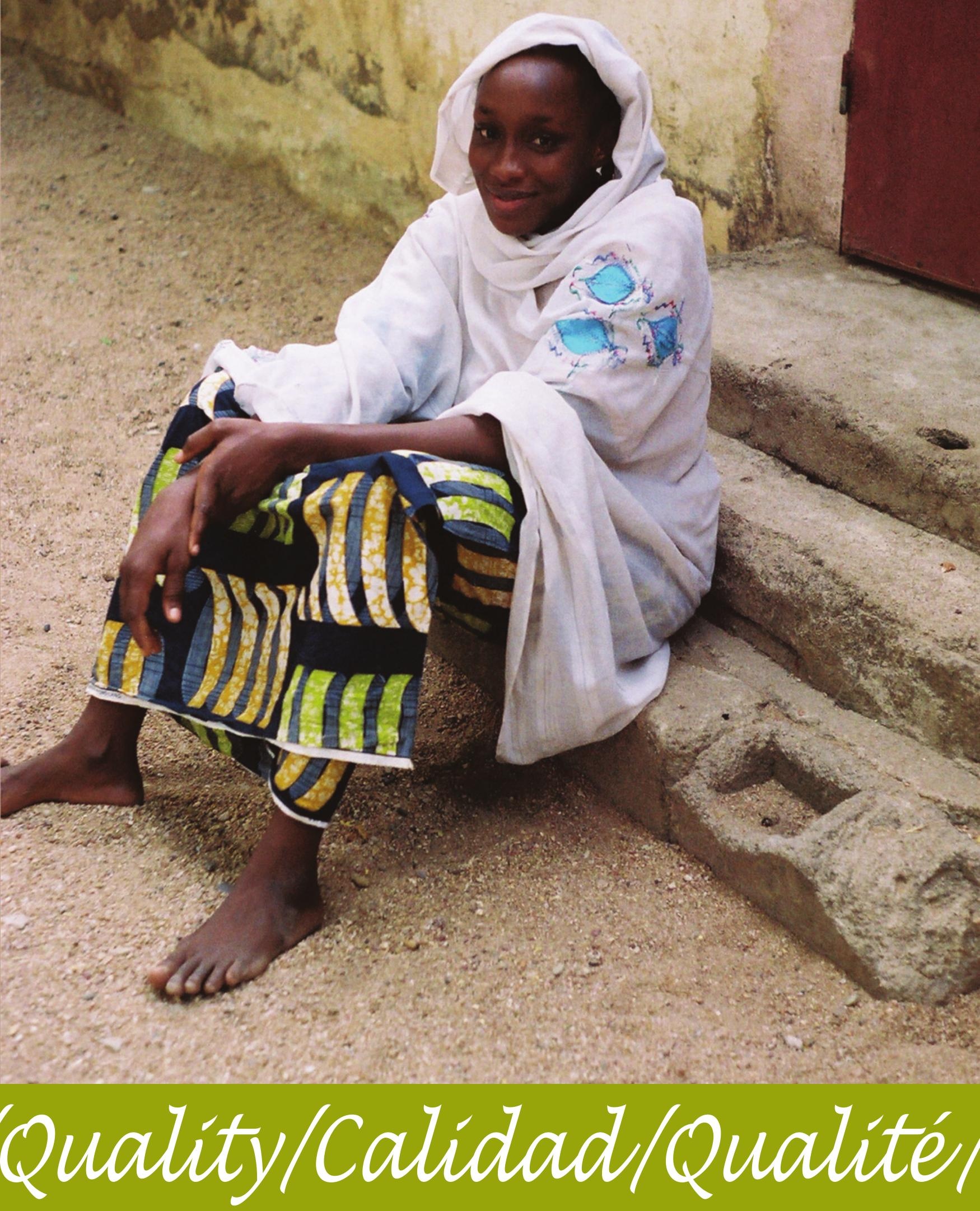




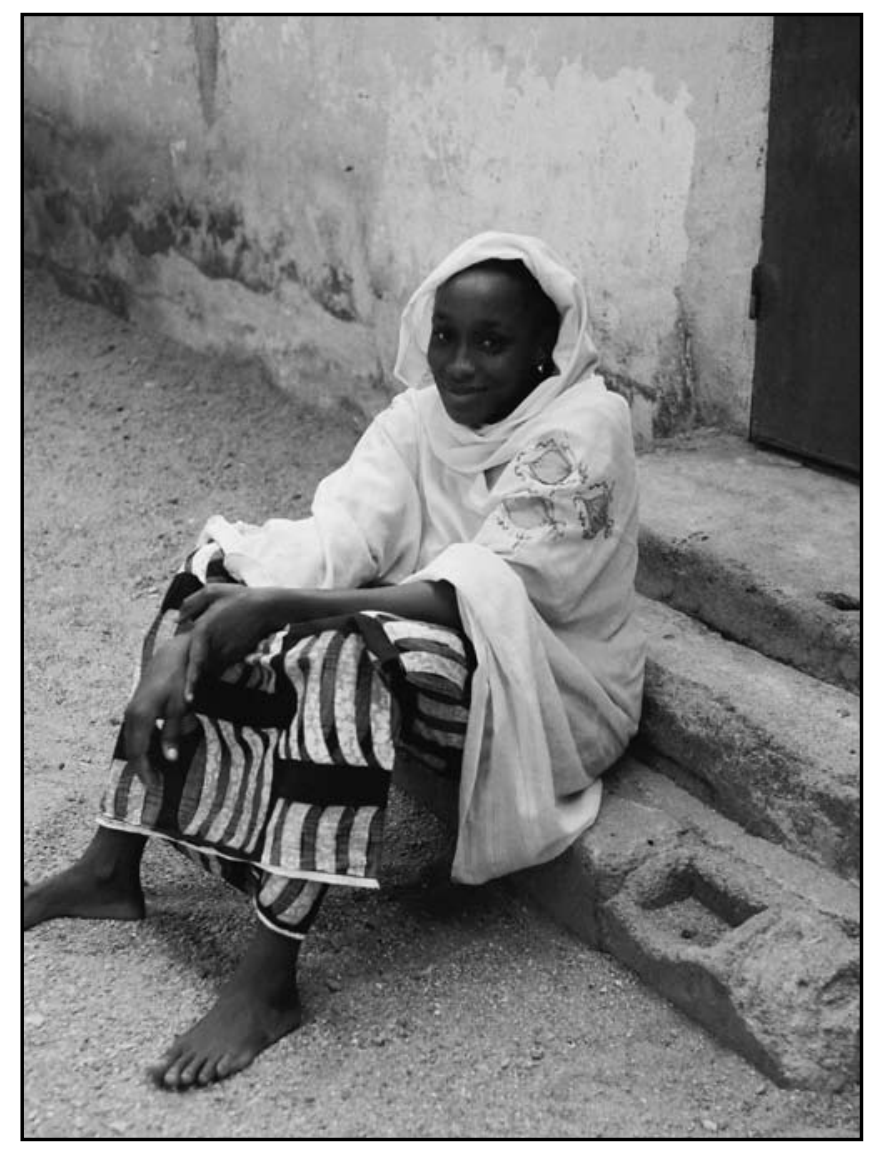

When Girls' Lives Matter: Ending Forced and Early Marriage in Cameroon

This issue of $Q / C / Q$ is dedicated to the memory of Tabita Damdam 
Quality/Calidad/Qualité, a publication of the Population Council, presents case studies of high-quality, innovative programs in sexual and reproductive health. $Q / C / Q$ specifically documents educational and clinicbased programs that are making strides in one or more of the following ways: (1) addressing the central importance of gender dynamics in shaping sexual and reproductive health outcomes; (2) improving the quality of care of clinic-based services; and (3) reaching disadvantaged and underserved groups. With rare exceptions, featured programs are operating in developing countries.

$Q / C / Q$ case studies - selected by an expert advisory group - are offered not as models for replication, but as examples for learning. They demonstrate a responsiveness to broader social and economic transformations; they highlight inventive and affordable ways to respond to clients' needs; and they reflect the self-critical and flexible attitude required for learning from program experiences and research evidence. Although they are written as practical tools-in accessible style with carefully selected detail-they also serve to inspire program leaders and policymakers to enable clients to become more effective guardians of their sexual and reproductive health, and by doing so contribute fundamentally to the achievement of such broader aims as the Millennium Development Goals.

\section{Production Staff}

Editor: Debbie Rogow

Assistant Editor and Production Coordinator: Jonah Stuart Brundage

Copyeditor: Karen Tweedy-Holmes

Designer: Mike Vosika

Translators: Edgar Peralta (Spanish) and Geneviève Haines (French)

\section{Advisory Committee}

$\begin{array}{ll}\text { Gary Barker } & \text { Katherine Kurz } \\ \text { Carmen Barroso } & \text { Laura Laski } \\ \text { Judith Bruce } & \text { Suellen Miller } \\ \text { Batya Elul } & \text { Saumya Ramarao } \\ \text { Susana Galdos } & \text { Ann Starrs } \\ \text { Françoise Girard } & \text { Cynthia Steele } \\ \text { Nicole Haberland } & \end{array}$

\section{(2 Population Council}

Publication of this edition of Quality/Calidad/Qualité is made possible by support provided by the Ford Foundation; the John D. and Catherine T. MacArthur Foundation; and the Poverty, Gender, and Youth Program of the Population Council. Statements made and views expressed in this publication are solely the responsibility of the authors and not of any organization providing support for $Q / C / Q$.

The Population Council—an international, nonprofit, nongovernmental organization-focuses on HIV and AIDS; poverty, gender, and youth; and reproductive health.

Population Council, One Dag Hammarskjold Plaza, New York, NY 10017 USA tel: (212) 339-0500 fax: (212) 755-6052 e-mail: qcq@popcouncil.org http://www.popcouncil.org

Cover photograph and all interior photographs by Andrea Lynch. The subject in the cover photograph is not associated with the program featured in this publication.

Issue No. 20 ISSN: 1097-8194

Copyright (C) 2011 The Population Council, Inc.

Any part of this publication may be copied or adapted to meet local needs without permission from the Population Council, provided that the parts copied are distributed free or at cost (not for profit) and that the source is identified. The Population Council would appreciate receiving a copy of any materials in which the text is used. 
The past decade has witnessed a dramatic increase in awareness about early and forced marriage of girls as a widespread violation of human rights. The implications of such marriages are now quite familiar: Girls are robbed of their childhood and the option of education, and are thrust instead into adult roles, often including forced sex and pressure to bear children early. They are more likely to experience domestic violence (Jensen and Thornton 2003) and frequently report unhappy conjugal relationships, even later in life. Because they are likely to marry men much older than themselves, they are also more likely to spend a significant portion of their lives widowed, abandoned, or divorced; those who are widowed are even more vulnerable because they typically do not own property or have the ability to earn a livelihood. In short, early and forced marriages exacerbate gender inequality and the likelihood of poor outcomes throughout life.

Although females' age at marriage has increased rapidly in most of the world, early marriage remains a common practice in many regions. According to UNICEF (2005), in South Asia, 48 percent of females aged 15-24 were married before the age of 18 ; in Africa, the proportion is 42 percent; and in Latin America and the Caribbean it is 29 percent. ${ }^{1}$ Substantial variation exists within these regions as well, with highest rates of child marriage typically among those countries with lowest levels of per capita income. For example, in Burkina Faso, Guinea, Bangladesh, Chad, Mali, and Niger, more than 60 percent of girls marry before age 18 (UNICEF 2005). In some settings - such as pockets of Uganda, Tanzania, Ethiopia, Nigeria, India, and Nepal - extremely early marriage and traditions of coercion in marriage remain common.
Why do traditions of early and forced marriage persist in certain areas when, globally, age at marriage has been rising? Efforts to analyze the influences on marriage decision point to a combination of economic and social factors, especially at the nexus between poverty and gender inequality. ${ }^{2}$ For example, several studies from India and Bangladesh report that parents often view daughters - who generally move to their husband's home and are not considered potential sources of support during parents' old age — as an additional burden (Cain 1981; Das Gupta 1987). Hence, parents are motivated to marry them off early

\section{Parents often view daughters - who generally move to their husband's home and are not considered potential sources of support during parents' old age - as an additional burden. Hence, parents are motivated to marry them off early to reduce the number of mouths to feed.}

to reduce the number of mouths to feed. Some evidence also suggests that concerns about daughters' safety, especially the fear of out-of-wedlock pregnancy, may be a factor in early marriage decisions. Moreover, evidence suggests that early marriage practices are also perpetuated by customs of dowry or brideprice, which involve significant payments directly from one family to another (Amin and Huq 2008).

Lessons from settings where age at marriage has increased are inconsistent. In East Asia, the increase in age at marriage is corre-

\footnotetext{
1 Under the Convention on the Rights of the Child, a girl is considered a child until age 18, except in countries where the age of majority is lower.

2 Other social factors, such as ethnicity and disability, may also influence girls' vulnerability to early or forced marriage.
} 
lated with gains in education and workforce participation that have given females greater choice regarding their partners. This effect, however, is not consistent. In the Middle East, delayed marriage appears to have occurred despite continued low education and lack of employment opportunities for women. Greater understanding of the causes and consequences of marriage decisions in diverse settings is needed to find effective pathways out of traditional harmful practices.

The complex and varied nature of forced and child marriage patterns is such that they have defied standard policy or programmatic actions. It is known that societies that impose such marriages typically afford low status to girls and women. Indeed, the violation of a girl's basic rights at the moment of marriage is typically tied into a web of mutually reinforcing violations throughout her life cycle. For example, in parts of north India, parents' expectation that the birth of a girl will carry not only lower social status but also high expenditures (for dowry payments at marriage) helps drive preference for boy as opposed to girl children, often leading to unfavorable birth ratios. Less investment in daughters often also leads to under-investments in their nutrition and education, further perpetuating their dependence on men and their low status.

In the absence of broader social and economic changes in women's status, few interventions have had an impact on harmful marriage practices. Legal remedies - those that set a minimum age for marriage, grant women the right to consent to or refuse a marriage, or ban marriage payments such as brideprice and dowry - have generally had little impact. These are at best blunt instruments, necessary but not sufficient to bring about the fundamental changes in attitudes toward girls and their rights. Even education, while important, may not exert an impact on its own. For example, in Bangladesh, a conditional cash transfer program giving parents financial incentives to keep their adolescent daughters in school succeeded in increasing secondary school enrollment but had no impact on marriage timing. The key in many places may be the promotion of schooling - particularly secondary schooling - combined with meaningful prospects of positive livelihood opportunities.

Combining public education about the negative effects of early and forced marriage with positive preventive strategies is also valuable. The Association for the Struggle Against Violence Against Women (ALVF, from its name in French) in Cameroon is one such example. ALVF provides counseling, language and literacy training, economic support, and empowerment activities for girls who have fled (or been thrown out from) early or forced marriages to help them overcome their adversities. At the same time, the program seeks to bring about broader social change by highlighting in the public sphere - as well as among parents and husbands - the plight of girls who were married early and/or by force. Hence, ALVF's prevention strategy is based on a broad understanding of the perceptions, expectations, and motivations that sustain the practice of early and forced marriage. That understanding is based on the experiences of the Cameroonian women who work, or seek help, at ALVF, which are shared in the following case study.

\section{References}

Amin, Sajeda and Lopita Huq. 2008. "Marriage considerations in sending girls to school in Bangladesh: Some qualitative evidence," Poverty, Gender, and Youth Working Paper No. 12. Population Council: New York.

Cain, Mead. 1981. "Risk and insurance: Perspectives on fertility and agrarian change in India and Bangladesh," Population and Development Review 7(3): 435-474.

Das Gupta, Monica. 1987. "Selective discrimination against female children in rural Punjab," Population and Development Review 13(1): 77-100.

Jensen, Robertand RebeccaThornton. 2003. "Early female marriage in the developing world," Gender and Development 11(2): 9-19. Cited in UNICEF. 2005. "Early marriage: A harmful traditional practice." <www.unicef.org/ publications/files/Early_Marriage_12.lo.pdf>. Accessed 14 October 2010. 


\title{
When Girls' Lives Matter: Ending Forced and Early Marriage in Cameroon
}

\author{
by Andrea Lynch
}

When Aïssa Doumara was twelve years old, her mother died and she was sent to live with an aunt. Her father was coming for dinner one night, and she prepared a special sauce for him. Asked by the aunt if he was pleased that his daughter could cook so well, Aïssa's father replied,

"Her husband is the one who will be pleased." More than twenty years later, Aïssa recalls that moment with perfect clarity. "It sent chills down my spine," she says. For Aïssa, her father's comment was a stinging reminder that in northern Cameroon, a girl's life was not her own. "In this region," she reflects, "if you're born female, you realize very quickly that your life is not going to be as good or as easy as your brothers' lives, as boys' lives. You know because it's always being repeated to you in one way or another - you're always being reminded that you don't really belong to your family. If you quarrel with your little brothers, your family says, 'Yes, but you'll be gone one day."

Aïssa was a strong student, consistently among the first in her class. Her father, however, had other plans for her. She had her first suitor at the age of eleven, and by the time she turned fifteen, her father had promised her to one of his own contemporaries - a man 21 years her senior.

By the following year, Aïssa was married to this man and sent to live with his extended family, whom she had never met. "I was so sad, I cried for months," she recalls. "I didn't want to do my hair, I didn't want to talk to anyone, I just wanted to go home. But it wasn't my home any more - I belonged to another family now. All of my unmarried classmates went back to school, but I just stayed in the house and cried. I couldn't even eat." Within another year, Aïssa became pregnant, the first of three pregnancies.

This story is typical of many young women who grow up in the far north of Cameroon, but Aïssa was relatively lucky: One of her husband's cousins urged her to resume her studies and her husband permitted her to do so. Overcoming the depression and inertia brought on by her marriage, she strapped her infant daughters on her back and attended classes by day, then returned to her domestic responsibilities in the evening. Upon completing secondary school, Aïssa received two scholarship offers, one to study in the Cameroonian capi-

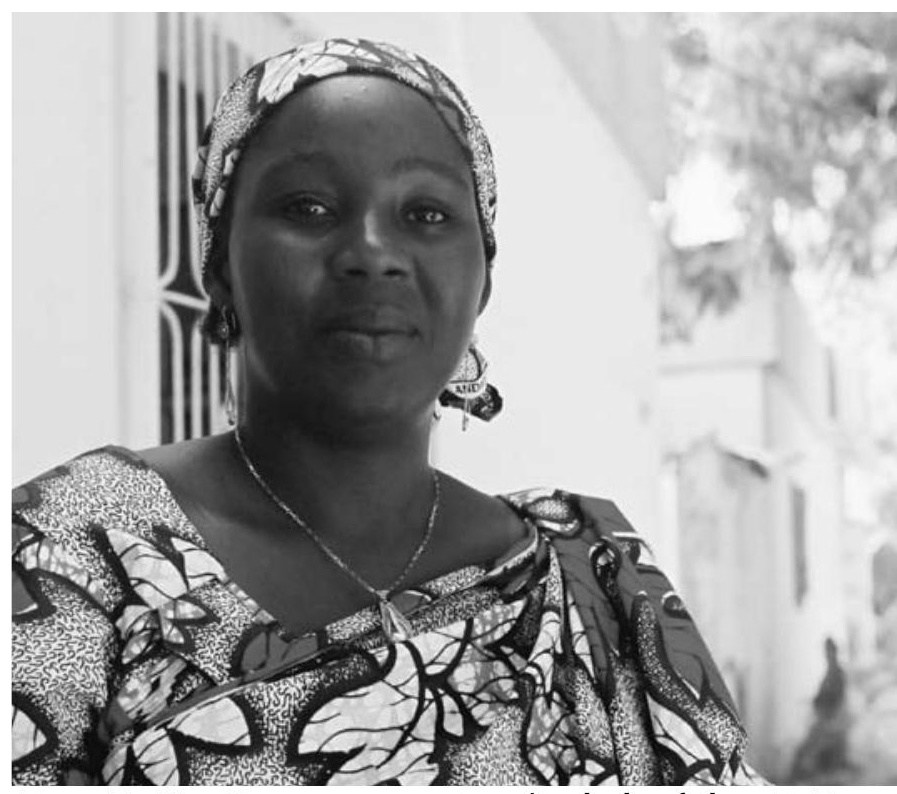

At age 11, Aïssa Doumara was sent a suitor by her father. At 16, she was pulled from school and married off to a 37-year-old man. Today she is a leader in the movement against child marriage. 
ciation for the Struggle Against Violence Against Women, a national organization she had co-founded with a group of childhood friends and cousins five years earlier. That goal took her to the Rotary Club dinner, where she hoped to interest a few women in her plan, and where she met Aïssa. Recalling that moment, Aïssa says, "My fight began when I was very young, and I always said to myself that I was going to work with someone who agreed that what I had lived through was not good, and that it had to change." She took one of Siké's flyers.

By March of that year, Aïssa, together with Siké and two other women - AnneMarie Njocké and Iris Hartvelt — had formed a Far-North province branch of the Association for the Struggle Against Violence Against Women, also known in French as ALVF. ${ }^{2}$

Siké Billé moved to Maroua to establish a chapter of the Association for the Struggle Against Violence Against Women Maroua. She chose Maroua because women in that region face such extreme discrimination, isolation, and violence. To gain initial acceptance, even to find a place to live, Siké pretended she had a husband working in the capital city.

tal of Yaoundé, 500 miles away, and one to study at a university in Germany. At her husband's urging, Aïssa declined both offers. Instead, she remained in Maroua ${ }^{1}$ and enrolled in a local professional course.

Aïssa's life changed in 1996. At a Rotary Club dinner she attended with her husband, she met a woman named Siké Billé. Siké, who comes from southern Cameroon, had recently moved to Maroua for a community development job with the Ministry of Water, Mines, and Energy. A sociologist and feminist activist, Siké had chosen this particular position for a reason. Women in Maroua suffer extreme discrimination, isolation, and violence, and Siké aimed to start a local chapter of the Cameroonian Asso-

\section{Early Marriage in Far North Cameroon: Law versus Reality}

In Cameroon, forced and early marriage is in fact illegal. The legal minimum age of marriage is 18 for boys and 15 for girls; the Penal Code further states that marriage must involve the consent of both parties, and it must be recognized by an official certificate. In practice, however, the law fails to protect most girls. Indeed, among currently married women aged 20-29 in the northern region, fully three-fourths were first married by age 16 (Adair 2007). Polygyny is practiced in this part of Cameroon, but multiple consecutive marriages are far more common than concurrent ones. Typically, when a girl is married off, it is to a much older man who may have had previous wives.

\footnotetext{
1 Maroua is the capital city of Cameroon's Far North province.

2 Cameroon is a francophone country and ALVF stands for Association de Lutte Contre les Violences Faites aux Femmes. The Association for the Struggle Against Violence Against Women is referred to interchangeably as the Association and ALVF throughout this article. The branch in the far north is one of three current branches of the Association.
} 


\section{The Birth of the Far North Branch of ALVF}

The vision that originally took Siké to Maroua was a broad one. She wanted to establish a feminist foothold in a part of the country where women had little say in their lives, with the eventual goal of transforming women's unequal status. An outsider to the region but an intuitive networker and relationship-builder, Siké spent her first few years in Maroua establishing herself - building a network of allies in the legal, medical, political, traditional, and religious communities; and leveraging every personal, professional, and political contact she had to garner support for the Association.

From the beginning, Siké knew that the Association's existence would provoke the accusations typically leveled at feminist organizations worldwide: that it was antimale, anti-marriage, and pro-prostitution, and that it sought to corrupt women, emasculate men, and disrupt social stability. In a highly conservative setting like Maroua, she knew she would have to work strategically. For instance, she knew that her status as a single, childless woman would harm her credibility and might even prevent her from finding a place to live. So she told her new acquaintances that her husband was a lawyer in Douala, and she introduced her nephew, who had come with her to Maroua, as her son. "When I realized that I was accepted, I started to tell people that I wasn't married - if they asked," she says. "But at the beginning I was obliged to lie in order for the Association to be accepted, so that I'd have allies in the right places, and so that we would be able to stay."

During her first two years, Siké was joined by a growing group of women like Aïssa. Together, they focused their efforts on identifying the kinds of violence faced by women in the Maroua region. Working out of a small room in the provincial office of the Ministry on the Condition of Women, they met with local authorities and with representatives from nongovernmental organizations (NGOs). With support from the Dutch development organization SNV, they organized a two-day workshop with about 20 influential individuals (doctors, teachers, social workers, traditional and religious authorities, jurists, and journalists).

\section{Siké wanted to establish a feminist \\ foothold in a part of the country \\ where women had little say in their \\ lives. As they listened, one issue \\ emerged again and again: forced \\ and early marriage}

Most important, they undertook informal, qualitative research with women in and around Maroua.

As they listened, one issue emerged again and again: forced and early marriage. Yet public debate about child marriage was virtually nonexistent: No organizations were focused on identifying and addressing its root causes, or on supporting the women whose lives had been torn asunder by this abusive practice [see box on page 4].

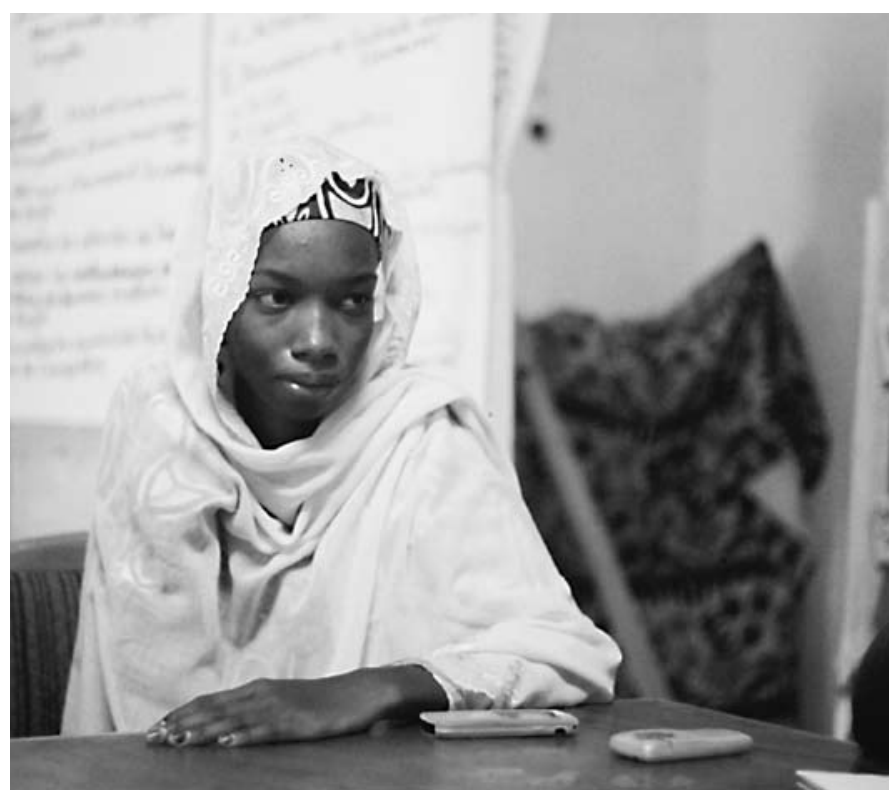

ALVF explains that at the root of child marriage is power and control over women. 


\section{Establishing the Center for Women's Lives}

A major turning point came in 1998, when the Association secured funding from the New York-based International Women's Health Coalition (IWHC) for the Far North Branch to open an office and drop-in center for women, the Centre Vie de Femmes (Center for Women's Lives). The grant included funding for a state social worker to spend 15 hours a week in the Center counseling

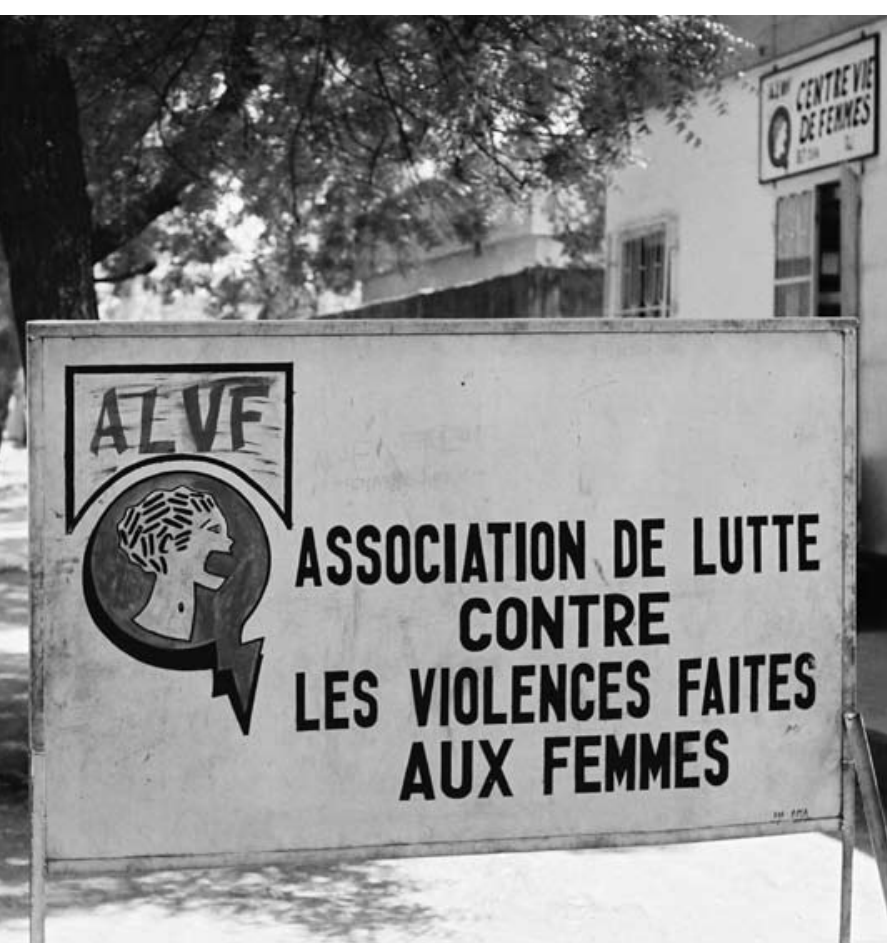

The Center for Women's Lives is housed in the ALVF building just down the street from the palace of the traditional leader. The choice of location was a risky, but strategic decision for an openly feminist organization.

and educating women. Establishing a physical space - with a sign out front — was a watershed moment for Siké, Aïssa, and their colleagues. Suddenly, the Association was visible and accessible to women. ${ }^{3}$
The creation of the Center also afforded independence from the Ministry, and thus, the Cameroonian government. Symbolically, it established the Association for the Struggle Against Violence Against Women as a permanent, visible, autonomous institution, and this in turn lent legitimacy to the issues and perspectives that the Association sought to champion. When the Minister for the Condition of Women paid a visit to Maroua in 1998, ALVF was the only women's NGO with a space equipped to receive her delegation.

In choosing a location for the Center for Women's Lives, Siké strategically rented a space on one of Maroua's main avenues, near the Lamidat, the palace of Maroua's senior traditional leader and the seat of the local traditional justice system. The close proximity to a landmark helps visitors find the Center. Even more strategic, if risky, was the assertive decision by a decidedly feminist organization to hang a prominent sign just down the street from the community's bastion of tradition. Announcing its existence in this manner to all who passed by was part of the Association's wider strategy: to establish an alternative voice capable of sparking debate and publicizing experiences that had been shrouded in silence, fear, and invisibility. In short, to make women visible.

The offering of services started very slowly, and in its first few years of operation, the Center handled only about ten cases a year. Siké and her colleagues used the time to learn more about these women's lives and needs, including what had led them to become trapped in a cycle of violence and dependence. Echoing what they had learned in their initial outreach, they found that, typically, these women's problems had been set off by a forced, early marriage.

\footnotetext{
3 The Center was equipped with a private counseling room, a small library, and a space to hold community-
} education sessions and public events. 


\section{Child Marriage in Far North Cameroon}

\section{Underlying Factors}

Girls who grow up in northern Cameroon are told early and often that marriage is their primary destiny. The Association for the Struggle Against Violence Against Women has analyzed the factors and social institutions that reinforce this message, which echo many of the underlying causes of early marriage elsewhere.

Child marriage is typically practiced in a context of poverty. Because of the prohibitive costs associated with schooling ${ }^{4}$, poor families often view educating their daughters — who are just going to be married anyway - as a dubious investment. Indeed, it is not uncommon for a young adolescent schoolgirl who talks out of turn to be reprimanded by her teacher and asked, "What are you still doing in school? You should be married by now!" Marrying off daughters is also an income-generation strategy. In exchange for the girl's "hand" in marriage, a father receives payment - usually in the form of livestock, cash, or goods; younger girls often fetch a higher price. Marrying off a daughter also means one fewer mouth to feed.

Moreover, some parents view marrying their daughters off as a strategy to protect against a potential out-of-wedlock pregnancy. Such pregnancies - even if they are a result of rape - are considered to bring shame on a girl's family and to undermine her marriage prospects. Indeed, while it is socially acceptable for a 12-year-old girl to be impregnated by her 40-year-old husband, an 18-year-old who becomes pregnant after a rape - or after having consensual sex with her boyfriend - is a source of shame. ${ }^{5}$

Yet another factor is confusion about religious law. The Koran calls for the consent of both parties in order for a marriage to be valid. In reality, child marriage is misrepresented as religious doctrine when in fact it is merely a local tradition. Very few people in the region, however, have enough literacy and training to read and interpret religious texts for themselves. Hence, many parents mistakenly think of child marriage as a religious value firmly rooted in the sacred texts of Islam (the dominant religion in this part of Cameroon).

Men - usually fathers and older brothers - negotiate the vast majority of child marriages; mothers are often left out of the picture entirely. Mothers know that resistance might lead to their being thrown out of the house. Indeed, the mother is often the

\section{Marrying off daughters is also}

an income-generation strategy.

In exchange for the girl's "hand"

in marriage, a father receives

payment - usually in the form

of livestock, cash, or goods;

younger girls often fetch a

\section{higher price.}

first person to be blamed when a girl refuses to comply with a proposed marriage.

Amid the many factors cited above, the practice of child marriage is kept in place by a single underlying reality: patriarchy and "male honor." Across Cameroon's far north region, women are considered property, and men's honor is paramount. The notion that a woman or girl has a right to decide whom she marries is predicated on the notion that she has the same value as a man or boy, a radical idea for many.

\footnotetext{
4 Even in the absence of tuition fees, parents must pay for clothes, transportation, and textbooks, as well as exam fees, activity fees, and contributions to local school boards.

5 For a post-pubescent unmarried girl in Maroua, simply walking with a classmate, an activity referred to as "se promener" (literally "walking around), may be viewed as tantamount to sexual immorality.
} 


\section{Girls' Childhood Path to}

\section{Early Marriage}

As a result of such attitudes, girls often don't make it into or out of primary school, so most women cannot read or write in any language and cannot speak French. ${ }^{6}$ Hence, they lack the skills that would not only afford them access to employment, but also equip them to interpret, analyze, and negotiate their external environment more effectively.

\section{Until their husbands begin to}

\section{demand sex - an act that}

sometimes involves the girl being

physically restrained by neigh-

bors or other family members -

most girls believe they are being

sent to visit an older relative or

\section{family friend.}

ried so young rarely understand what is happening to them. Until their husbands begin to demand sex - an act that sometimes involves the girl being physically restrained by neighbors or other family members - most girls believe they are being sent to visit an older relative or family friend.

As Germène Malana, the director of the Center for Women's Lives, puts it, "The system has taught them that a girl only has value behind a man, behind a husband." Still, many girls do not wish to be married. But a girl is less likely to resist her father's will because she knows that doing so may cause her father to punish her mother. Moreover, these marriages take place under customary or religious law; they are not legal and they involve little more than a handshake deal between the two families.

Of course, early marriage is often followed by early childbearing. Between 2004 and 2006, 27 percent of births recorded in the maternity wards of Maroua were to adolescent girls (Doumara and Billé 2007). Child brides are also at higher risk of complications from pregnancy and childbirth, including obstetric fistula. HIV/AIDS (now at a national prevalence rate of 5.5 percent) is also a growing concern, especially since girls are often married multiple times to older men who have had multiple partners. Although HIV prevalence is lower in the northern part of Cameroon than in the south, women across the country face higher infection and prevalence rates than their male counterparts. This phenomenon is most pronounced among young women: HIV is over three times as prevalent among women aged 15-24 as it is among their male peers (Adair 2007).

\footnotetext{
6 Fewer than one in four women in the province is literate (UNESCO 2009). Fulfulde is the primary language in Cameroon's Far North Region.
} 


\section{A bandonment by Husbands}

After finding themselves married and in a situation with no say of their own, many girls are just as readily abandoned, a prospect that is all the more likely due to the informality of most marital arrangements. As Hamadou Bachirou, a local chief who has worked with ALVF for a decade, reports, "Men here divorce women on any pretext, with impunity, without any sense of what they're doing."

Lacking an official marriage certificate, "divorced" girls have little grounds to seek support from their ex-husbands for any children they have been left to feed and care for. Often, their families of origin refuse to take them back in, exasperated by the additional mouths to feed. They are generally uneducated, without a means of generating income, and lacking the selfesteem and supportive social environment that would allow them to strike out on their own. For most, the only end to their predicament is to enter into another marriage; for some, the only option is transactional sex. As Maimouna Masky, one of the Center's social workers, explains,

[Girls are] repudiated because they don't know their rights, they just accept whatever their husbands say. They were married prematurely; at the age of fifteen, what do you know? The husband doesn't understand that she's a child, he says that she's his wife, that she has to do this and that. Then he rejects her, maybe when she gets pregnant he loses interest. [He complains that] she doesn't know how to mend his clothes, she's negligent, she's not prepared for marriage, so he throws her out. She goes into a second marriage. By the time she turns sixteen, she's already pregnant again in someone else's household. I've seen twentyyear-old girls who have already had four husbands.
These are the conditions that lead women and girls to the doorstep of the Center for Women's Lives. To be sure, women, girls, and their families seek the Center's services for a range of reasons. Most are looking for some form of support for the children of out-of-wedlock pregnancies or marriages that have since dissolved. Some come because they or their daughters have been raped. Some come because they suspect that they are HIV-positive. Some come to seek protection from violent husbands. Despite this diversity, however, the vast majority of women have one thing in common: They were married young and against their will, usually to much older men, and often more than once. It is for this reason that Aïssa, Siké, and the staff at the Center for Women's Lives have come to see the practice of forced and early marriage not only as symptomatic of deeper inequalities

Among clients at the Center for

Women's Lives, the average age

of first marriage is 13-14 years,

although some clients have been

as young as 10 years old.

between men and women, but also as the root of almost all of their clients' subsequent problems. As Maimouna explains,

A woman might come in because of an out-of-wedlock pregnancy - that's what she says because that's her immediate problem. But when we enter into her story, we learn that she was married as a girl, then rejected, and now she's here with this problem... That's why we say that ninety percent of the cases we deal with are cases of forced and early marriage. 
Germène Malana, the Center Director, puts it more simply: "The beginning of the cycle is being married. Everything else is just the consequences." Mobilizing to address those consequences in such a challenging environment - where the majority of the population lives in extreme poverty, where the nearest university is over 200 miles away, where most girls receive little to no schooling and have no means of earning an income, and where women enjoy few rights in the private sphere and little representation in the public sphere - is a daunting task. But over the past ten years, the Maroua branch of ALVF has grown from a weekly meeting of concerned women to an established institution that not only serves hundreds of women a year, but has also succeeded in sparking debate on a practice once shrouded in silence.

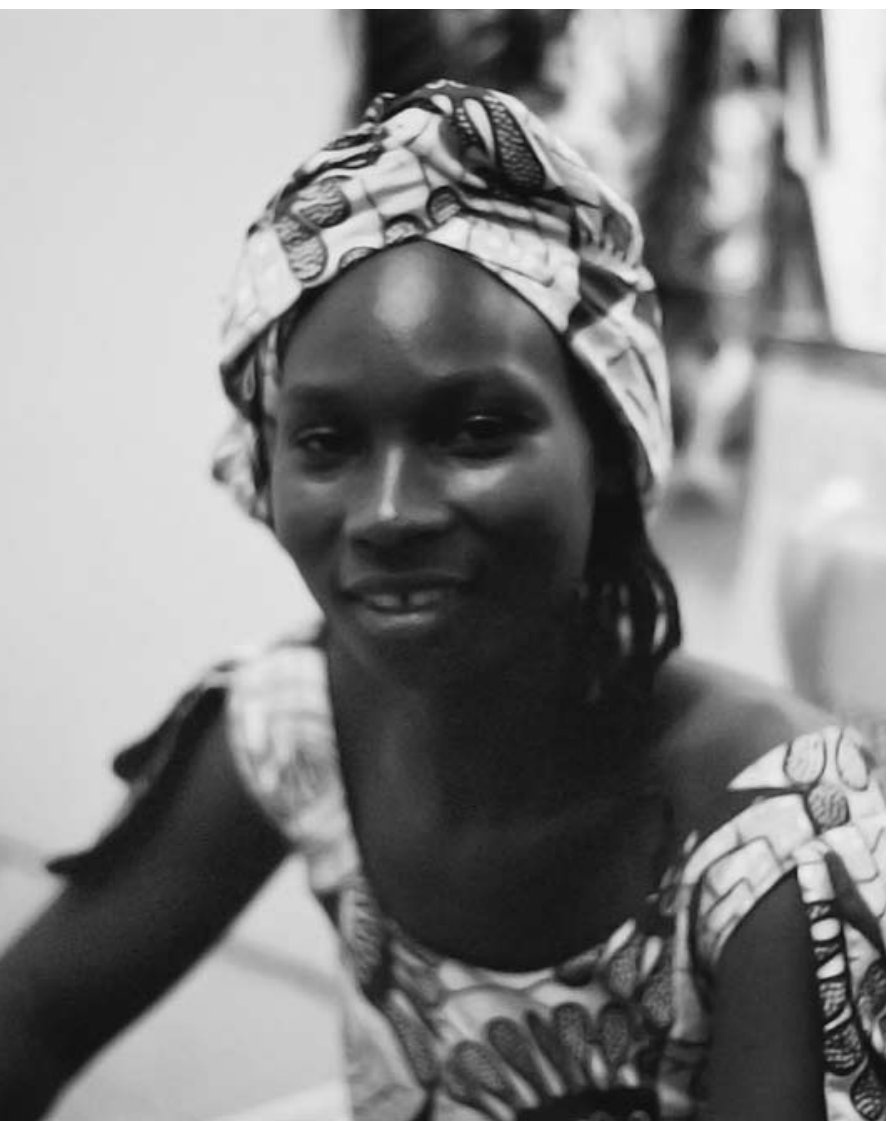

Germène Malana is the Director of ALVF's Center for Women's Lives.

\section{A Feminist Vision}

Siké Billé's feminist awakening — or prise de conscience, as she calls it - came in the 1970s while she was studying sociology at the University of Paris. Siké was familiar with feminist ideology but was not convinced of its relevance to her life. Instead, she participated in a left-wing opposition party with fellow Cameroonian students, an experience that inadvertently sparked her feminism. She recalls:

Since it was an underground movement, all the members didn't get together at once, instead we worked in small groups. So I was in a group of four or five people who would get together and work all night, and in the morning, we would split up. I was the only woman in the group. And I realized that every time we got together in this working group, when the moment came to make a meal, it was me who they called. When the moment came to make coffee, I was the one who was expected to do it. And that was the moment when I said to myself, in fact, the discourse of feminism is true.

Siké's feminist awakening mirrors that of many women from the global South who developed political consciousness and practical organizing skills by participating in leftwing, post-independence, post-dictatorship movements, but quickly came to realize that transforming unequal power relations between men and women was not, in fact, part of the "revolutionary" agenda. Although she did not know it at the time, Siké's cousins and close friends Esther Endalé and Ngobo Ekotto (who were studying in Lyon and Toulouse, respectively) were experiencing similar transformations. On the eve of an International Women's Day celebration held in Paris in 1979, both Esther and Ngobo contacted Siké to let her know — somewhat sheepishly - that they would be coming to town for the feminist events. The three women met in Paris, thousands of miles from home, and vowed that one day they would take their activism home to Cameroon. 
Siké, Esther, and Ngobo, joined by four other women, founded the Association for the Struggle Against Violence Against Women in 1991, in the capital city of Yaoundé, after the more overtly political Women's Collective for Renewal — their original organization - was banned by the Cameroonian government. The founders volunteered, building the organization in their free time. They immediately settled on a broad definition of violence against women - encompassing physical, psychological, sexual, political, social, and economic dimensions - as both a theoretical framework and the practical focus of their work.

From the start, ALVF has been guided by a feminist vision that embraces both the abstract notion of gender equality and a theory of social intervention that puts women's experiences and concerns at its heart. In this way, Siké and her colleagues have sought to address both women's immediate, practical needs and their deeper strategic interests [see box].

\section{Practicall Needs and Strategic Interests}

With the Center for Women's Lives, Siké and her colleagues had created a safe space where women knew they would be trusted, believed, listened to, and supported. But they still lacked a concrete, sustainable strategy to help women transform their daily lives.

That began to change in 2000, when Siké attended a three-week training on applying gender analysis in the work of development NGOs, organized by the German organization Inwent - Capacity Building International. ${ }^{7}$ During the course of the training, Siké was particularly struck by a new framework: the distinction between women's practical needs and their strategic interests. As first elaborated by feminist sociologist Maxine Molyneux and later popularized by development anthropologist Caroline Moser, practical needs are women's day-to-day requirements of survival, arising "from the concrete conditions of women's positioning within the gender division of labor" and "formulated by the women who are themselves within these positions." Strategic interests, on the other hand, "arise from the analysis of women's subordination and from the formulation of an alternative, more satisfactory set of arrangements than those which exist" - essentially the transformation of societal norms and power relations (Molyneux 1985: 232). Although women's practical needs may arise out of a discriminatory system, fulfilling those needs does not necessarily challenge that system. In addition, women may not readily support — and might even be opposed to - efforts to achieve their strategic interests because such efforts may actually undermine their practical needs in the short run.

This framework taught Siké and her colleagues that efforts to achieve women's strategic interests (for example, to eliminate inequality in marriage) must take into account their practical needs (for example, to feed themselves and their children). It also provided them with analytical tools to translate ALVF's feminist vision into a series of concrete activities both to address women's daily challenges and to lay the groundwork for deeper social transformation. As Siké puts it, "you need to show that girls' practical needs can be resolved in the course of the struggle." But focusing on the Center's clients' practical needs to the exclusion of their strategic interests also does women a disservice. As Germène points out,

Satisfying a woman's practical need is not sufficient for the vision that we have of changing people's mentalities, changing people's behavior. A survivor or a victim who leaves the Center might come back tomorrow or the next day with the same problem, because satisfying her immediate need would not have helped her affirm herself and mobilize against the real problem.

Thus, the key insight of the gender workshop was not the necessity of separating efforts to address women's practical needs from efforts to address their strategic interests, but rather the imperative to combine them.

7 Internationale Weiterbildung und Entwicklung gGmbH in German. 
Armed with this vision, the Far North Branch was able to develop a comprehensive institutional strategy that linked service provision, advocacy and lobbying, alliance building, awareness raising, and communications. The staff's efforts were informed by the experiences of the women they served every day at the Center and by

In addition to providing women who attend the Center with direct services, the staff of ALVF carry out advocacy and lobbying, alliance building, public education, and communications. their own commitment to place the woman and her concerns at the core of their thinking and action. Beginning in 2000, they started putting together an empowerment program that would provide the women who came to the Center with both support and tools to analyze and negotiate their environments, to build alliances with each other, and to work collectively (and therefore strategically) to satisfy their practical needs.

Enabling girls and women to participate in public life is an important element of promoting their rights and well-being. To this end, in 2001, the Far North Branch of ALVF initiated a citizenship project that helped girls and women obtain national identity cards and, in preparation for Cameroon's 2002 national elections, educated

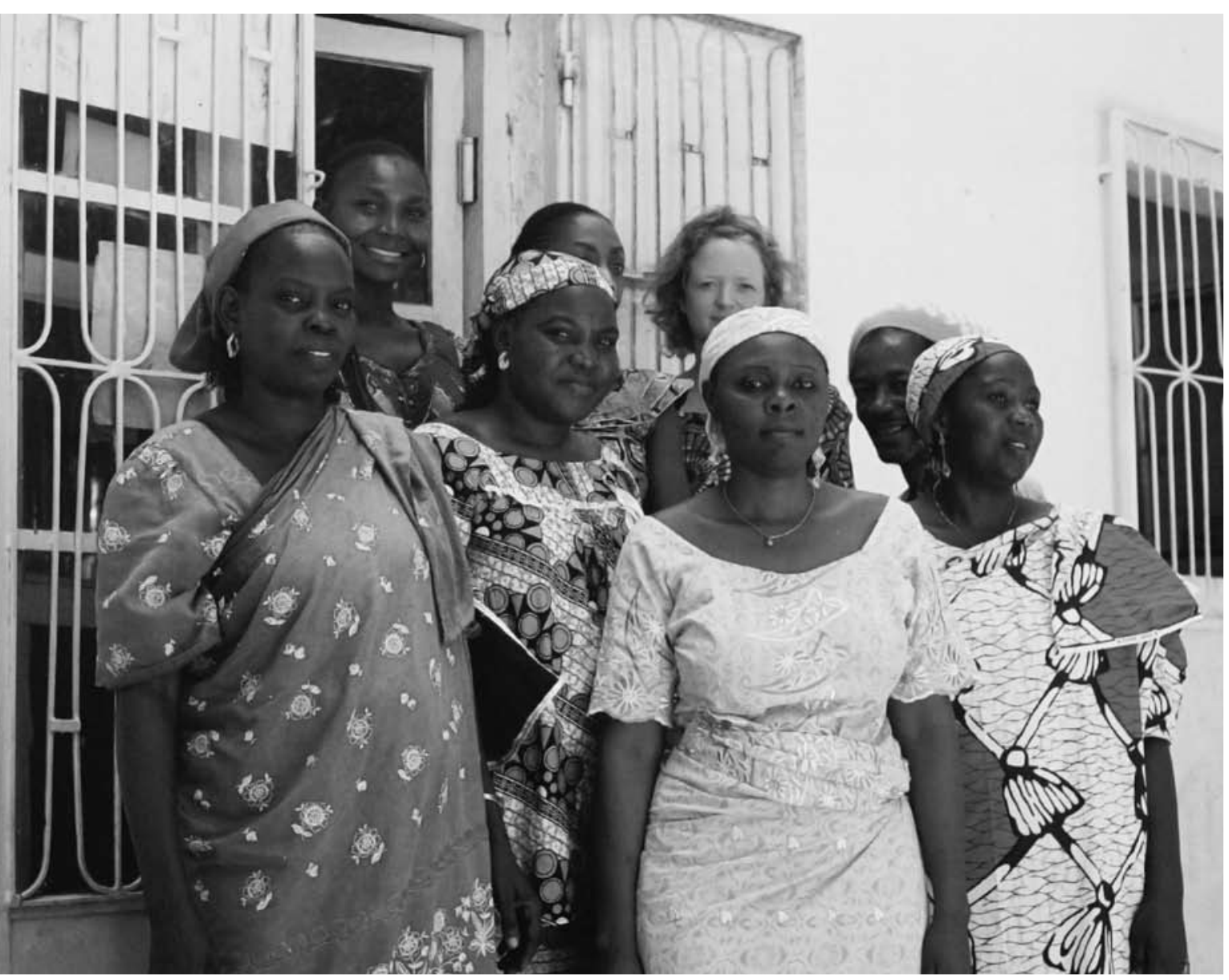

The proud staff of the Maroua chapter of the Association for the Struggle Against Violence Against Women. 
them on how to select candidates who would represent their interests. In 2005, the Center added free classes in functional literacy and French. These group activities also provide opportunities for clients to connect with each other.

ALVF members also learn from the women about their lives and needs. As Siké explains, in this way the women who seek the Center's services become actors in the process of change, and a central part of the base that the Association is building:

You as a woman, another person cannot express what you feel, only you can do that. We can't start talking about forced and early marriage if it doesn't come from girls who have lived these marriages.

This model is not intended to reach huge numbers of clients, but rather to catalyze substantive changes in the lives and consciousness of a small number of women. Even today, the Center has a client base of only about 200 women a year. At the same time, ALVF continues to work directly with the power-holders in women's lives - traditional and religious authorities, parents, politicians, administrators, and service providers - challenging them to become part of the change process and, in turn, creating a more supportive environment for individual women seeking to make changes in their lives. As Germène explains:

[The vision] is to achieve social change - to change mentalities - so that discriminatory practices, and specifically forced and early marriage, stop. The Center . . . measures the extent of the phenomenon; it generates concrete findings. With these findings, ALVF works to influence decision-makers so that they will be favorable toward a wider change in attitudes.

As the Far-North branch has evolved, the staff has grown from a small group of volunteers providing women with ad hoc support to an established institution that is known throughout the province. ALVF now operates two Centers in the Far North: the original site in Maroua, and since 2005, a smaller satellite center in Kousséri, located 130 miles to the north on the border with Chad.

In addition to Siké, Aïssa (who currently serves as program director) and Germène (who directs the Maroua center), several other staff have joined the Association. One early hire was cashier Tabita Damdam, ${ }^{8}$ who is a survivor of child marriage. Social worker Maimouna Masky was an-

ALVF's client base is small - only

about 200 women per year. But

with and through these women,

the organization is working with

powerholders in the community

to engage them in the process of

\section{change.}

other early hire. A part-time instructor was added in 2005 to teach functional literacy and French, and in January 2007, psychologist Justine Moukouri and social worker lya Gorsou were hired to help with counseling and support services. ${ }^{9}$

\footnotetext{
8 Sadly, Tabita Damdam passed away as this article was being prepared for publication; the authors and editor have kept the references to Damdam (as she was affectionately known) in the present tense. This issue of $Q / C / Q$ is dedicated to her memory.

9 While the International Women's Health Coalition continues to fund the Center's operating costs, support from Cordaid has enabled the substantial institutional growth that has taken place in the past few years.
} 


\section{A Visit to the Center for Women's Lives}

On a typical day, women filter in all morning to speak to one of the Center's two social workers, or to the psychologist who sees clients two days a week. In the afternoons, women gather for classes. They learn basic French (their first language is Fulfulde) along with information about such topics as sexual and reproductive health, citizenship, violence, girls' rights, and the causes and consequences of forced and early marriage. Periodically, the Center holds opendoor days, inviting members of the surrounding communities to learn more about and become involved with its work.

Women and girls hear about the Center from a variety of sources, including word of mouth, community outreach events, radio, the Center's own sign, other organizations, and state agencies. From the moment a woman first enters the Center, it is she who decides how her case will unfold. As the social workers explain, their job is not to tell a woman what to do; it is to accompany her for the duration of her process and remain her unwavering ally along the way.

The significance of merely providing a space for women to tell their stories, and to have their stories be believed, cannot be overstated. As social worker lya Gorsou explains:

There are some cases where the women come in crying. We sit with you while you let it all out and have a good cry. Afterwards, we ask you, gently, what the matter is, and we let you know that you can trust us.

The social worker provides the client with the information she needs to make informed decisions at each juncture and refers her to other service providers or institutions based on her specific needs. For example, victims of domestic violence and sexual as-

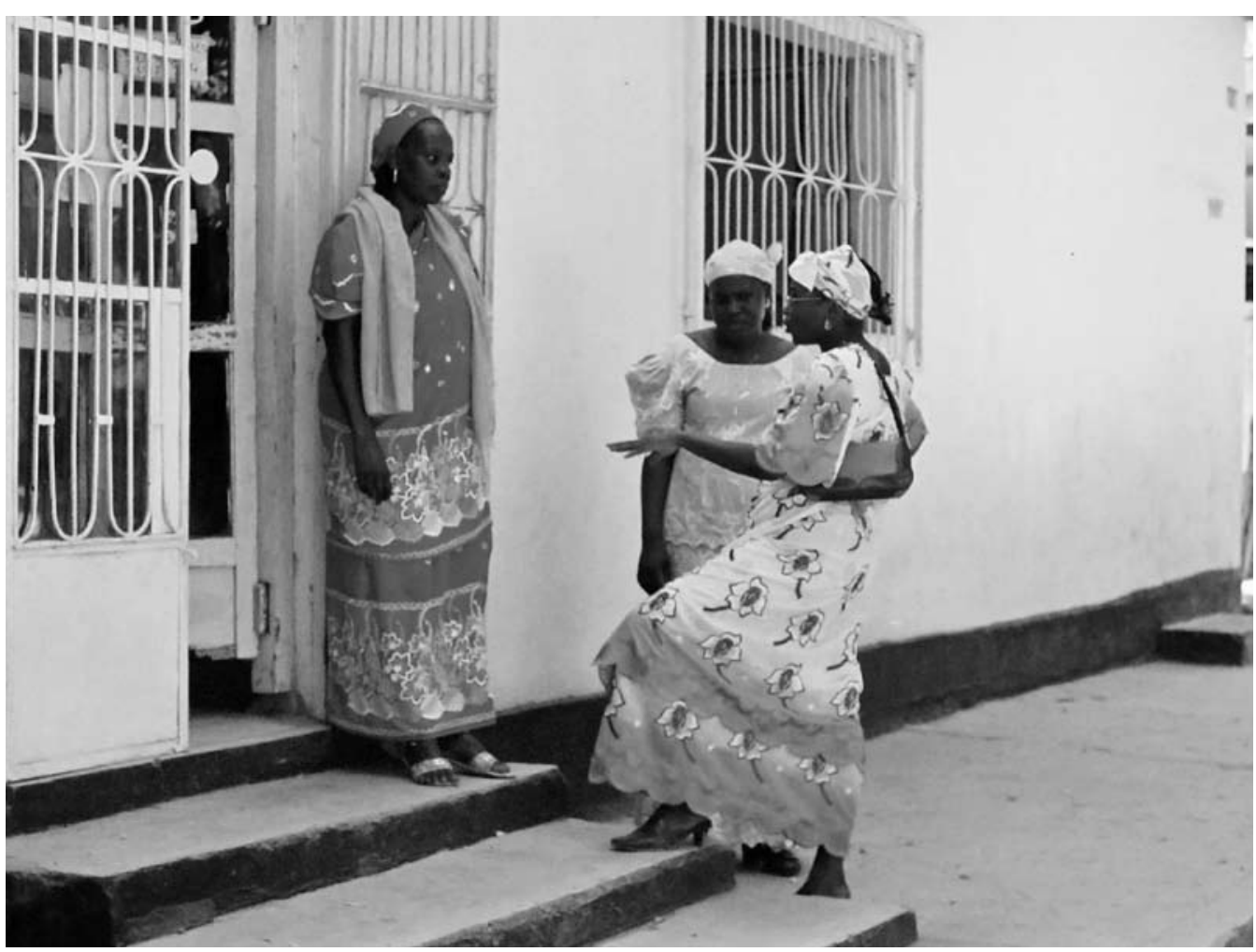

ALVF has expanded to include two Centers in the Far North. Pictured above are staff from the Maroua Center (Maimouna, far left, and Damdam, center) with a co-worker from the Kousseri Center. 
sault are taken to the hospital to secure a signed medical certificate from a doctor; women who learn that their husbands are HIV-positive are accompanied throughout the testing process. Maimouna explains, "We accompany the victims because they don't know their rights, they can't read or write, they don't understand certain things." Throughout, the social workers also educate their clients and their clients' families about girls' rights and encourage them to participate in the Center's various classes.

After an in-depth intake interview, the social worker and the client work to come

\section{The "Portrait":}

\section{A Needs Assessment and Monitoring Checklist}

Staff have learned to screen for those risk factors common among clients who have fled - or been thrown out of - early marriage. These include:

- Age 15-25

- Abandoned by her partner while pregnant or with one, two, or three children in her care

- Ignorant of her rights

- Traumatized by the experience of having been married at 13-16

- Excluded from services available in her area

- Rejected regularly

- Multiple partners

- Married illegally without a marriage certificate

- Deprived of a birth certificate or a national identity card

- Illiterate

- Deprived of financial resources

- Deprived of control over her sexuality

- Exposed to HIV/AIDS and other STIs

- Exposed to prostitution

- Exposed to early and unwanted pregnancies

- Socially rejected

- Vulnerable to suicide
The significance of merely providing

a space for women to tell their

stories, and to have their stories be

believed, cannot be overstated.

to a mutual understanding of what each party expects. ALVF pledges to accompany the client throughout the duration of her case. In return, the client agrees to provide or obtain the needed documents — such as birth certificates for her children, a national identity card, or a marriage certificate - and agrees to honor her meetings with the social worker and anyone else to whom she is referred. This commitment, documented in a Client Agreement form, helps optimize the staff's ability to resolve the client's practical needs; it also builds the client's awareness and skills in ways that help her move toward realizing her strategic interests.

Following this first meeting, the social worker fills out a case analysis tool and a client profile checklist. She uses the analysis tool to document successes, failures, facilitating factors, and obstacles related to the case. (For example, a facilitating factor might be "Victim committed to pursuing her choice through to the end," and an obstacle might be "Aggressor refuses to respond to our summons.") On the client profile checklist, which itemizes the characteristics typical of survivors of forced and early marriage [see box], the social worker creates a quick "portrait" of the client by checking off those characteristics that correspond to the girl she has just seen. (In fact, this checklist is called the "Portrait.") The social worker fills out another portrait midway through the case, and a final one when the case has been resolved. Together, the portraits serve as a needs assessment, a monitoring tool, and an efficient means of collecting client data that can in turn be used for donor reports, project proposals, and public advocacy. 


\section{Case Management}

The most common case is a request for a pension alimentaire (food allowance) from the father of the woman's or girl's children. Some women are pregnant or have children as a result of union libre (sex outside of marriage), some from husbands who have since abandoned them, and some as a result of rape. If a client's children are the product of a child marriage, the social worker immediately seeks the girl's permission to arrange a meeting with her exhusband at the Center for Women's Lives. If he agrees, the social worker meets with him individually first, both to ensure that he does not pose a danger to the girl, and

With a client's permission, staff

may seek out a woman's ex-

husband with regard to her

request for child support. They

inform him that marrying an

adolescent without her consent is

illegal. Maimouna explains, "When

you open those documents, they

don't take it lightly. You tell them:

'It's not me, it's the law that says

this. You're Cameroonian."

to establish ground rules for the meeting that everyone will have a chance to speak, and everyone's voice will be respected.

Many men refuse to respond to a summons sent by a woman, so if the husband ignores the social worker's requests, she goes to see him at home. She inquires if he was married to the girl, and if he is the father of her children, then asks him to sign a paternity declaration. She explains that marrying an adolescent without her consent is illegal according to the Cameroonian Penal Code, as well as the African Charter on Human and People's Rights, the Convention on the Rights of the Child, and the Convention on the Elimination of All
Forms of Discrimination Against Women, all of which have been ratified by Cameroon. "When you open those documents, they don't take it lightly," Maimouna says. "You tell them: 'It's not me, it's the law that says this. You're Cameroonian."'

The social worker then explains to the father that he can either agree to pay a monthly sum to ensure that his children have enough to eat, or he can settle the matter in court, where he will be subject to charges of rape, since he was technically married to a child. Most of the time, the man agrees to pay the monthly sum. He signs an agreement, and he leaves a monthly payment at the Center. When the woman or girl arrives to collect it, the social workers check in with her; this may be a time to provide ongoing emotional support, or to encourage her to enroll in the literacy classes or the information sessions on girls' rights, citizenship, and early marriage. The monthly sums partially alleviate women's urgent need to feed themselves and their children, which also makes it easier for them to participate in these Center programs.

If the man refuses at the outset to acknowledge or fulfill his parental responsibilities, the client has the option of taking her case to court, either through the Cameroonian justice system or the Lamidat's traditional tribunal. (A man who initially signs a paternity declaration and child support agreement but then fails to make payments is revisited by the social worker; if he does not resume payments, he too may be taken to court.) The social worker accompanies the client throughout the duration of her case, helping her to file the necessary paperwork, supporting her in court, and working in partnership with allies inside the justice system. Although ALVF has won several cases on its clients' behalf, court cases tend to drag on for months or even years and entail a series of fees that are usually prohibitive for clients. For that reason, the social workers often advise women to begin by trying to settle the matter out of court. 


\section{Sample Cases from the Center for Women's Lives ${ }^{10}$}

Hawa's father went to consult an elderly marabou, or traditional healer. Unable to pay his bill, he offered 11-year-old Hawa to the 70-year-old. The girl, scared and distraught, resisted the marriage. A neighbor who heard the story approached the Center for Women's Lives to see if they could intervene. Center staff went to see Hawa, then Hawa's father; they explained to him that his daughter had rights, that what he was doing was illegal under Cameroonian law, and that they were prepared to take him to court. He agreed to abandon his plans, and Hawa remained at home.

Princesse, who had been married against her will as an adolescent, tried to seek a divorce from the Lamidat when her husband became abusive. The Lamidat granted her request for a divorce, but ordered her husband to pay the equivalent of only a dollar a month in child support. After Princesse turned to the Center for Women's Lives, Maimouna went directly to the ex-husband,

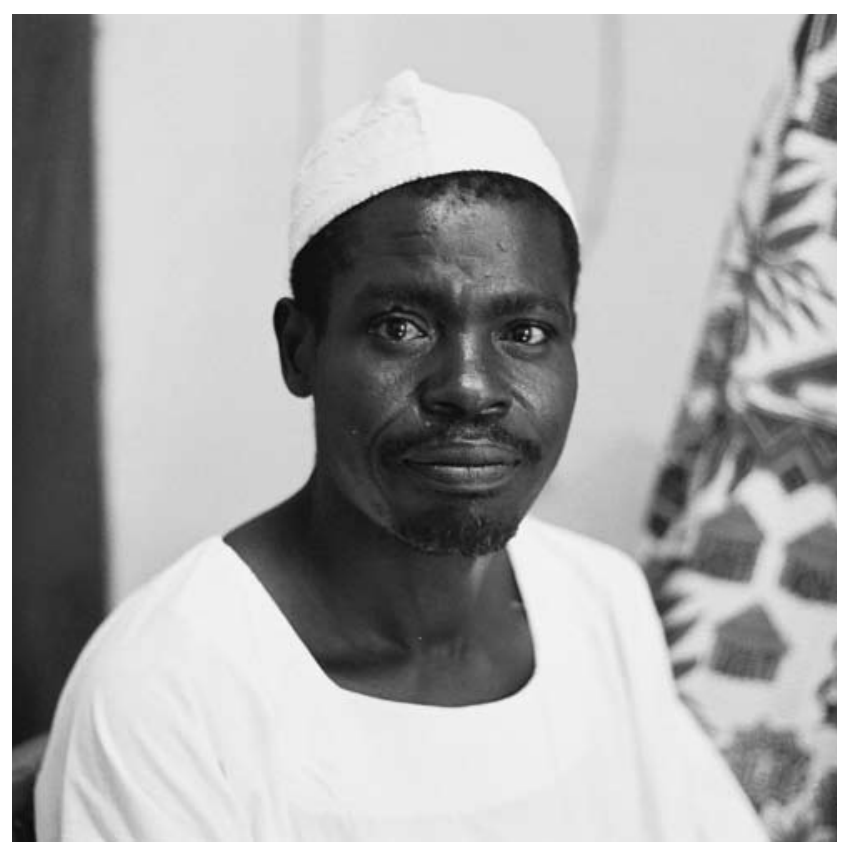

Amina's father has changed his mind about child marriage.

10 Pseudonyms are used for clients. detailed the costs associated with feeding and caring for a child, and explained that his marriage - of which the child was the physical evidence - had been illegal. After their discussion, the ex-husband agreed to raise his payments to sixteen times the amount ordered by the Lamidat.

Amina is 12 years old and lives with her mother and father, who are farmers. When she was 11, Amina learned from a friend that her father was planning on marrying her off to one of his friends, as punishment for her disobedience at home and because she was seen "walking around." Amina ran away from home, seeking refuge with a family friend, who put her in touch with Maimouna. After conducting an initial interview with Amina, Maimouna went to see her father, explaining the potential consequences of early marriage and that the practice was illegal. He signed a paper agreeing that he would not send Amina to be married without her consent, and that he would send her to school when the new term began.

When I spoke to him a few months after the school year began, he explained that he still lacked the means to send Amina to school. But he added that he had not understood the consequences of child marriage until Maimouna came to see him, and that he no longer believes in this kind of marriage. Asked what kind of husband he would like Amina eventually to marry, he replied, "It's not my problem - it's up to her. She's the one who will choose."

I also spoke with Amina and asked why she had resisted being married. Looking at me sharply, she stated, "I'm too little." 


\section{Dealling with Parents}

The majority of girls who arrive at the Center are accompanied by their parents. This can frustrate the social workers' attempts to let girls' desires and decisions guide the process, as most girls are reticent in their parents presence. In addition, parents and daughters commonly arrive with different objectives. Even so, the parents' presence provides a valuable opportunity for direct education and awareness-raising about the consequences of forced and early marriage, especially in cases where a girl has been abandoned by her husband. As Maimouna explains,

The parents forced the girl to get married, and now they come here to satisfy their own interests . . . They ask us to make the father of her child take responsibility. It's at this moment that we explain to the girl's father, "These are the consequences of what you've been doing since who knows when - maybe for the last ten years! Voilà! Here are the consequences of forced and early marriages.

Of course, the social workers will do their best to ensure that a girl's ex-husband takes financial responsibility for his chil- dren, if that is what the girl wants. But the emphasis is on girls' rights and parents' responsibilities - backed up by information sessions that parents are encouraged to attend with their daughters. In the absence of this pressure and information, parents are likely to force their daughters into another marriage, or leave them to fend for themselves. The social workers emphasize the consequences of such actions: girls with repeat marriages are vulnerable to further repudiations, dangerous reproductive health problems, and HIV/AIDS, and girls who are thrown out of the house with their children have few options for survival. As Tabita Damdam, herself the survivor of child marriage, emphasizes,

We try to make the parents understand that if your daughter leaves her marriage, you cannot abandon her. Because if you abandon your daughter, you push her to do bad things, you push her to go looking for food at a man's house, and when a man gives her something to eat, that's an exchange. He's not giving her something to eat for free. So if she comes home, you have to treat her like you did before she got married.

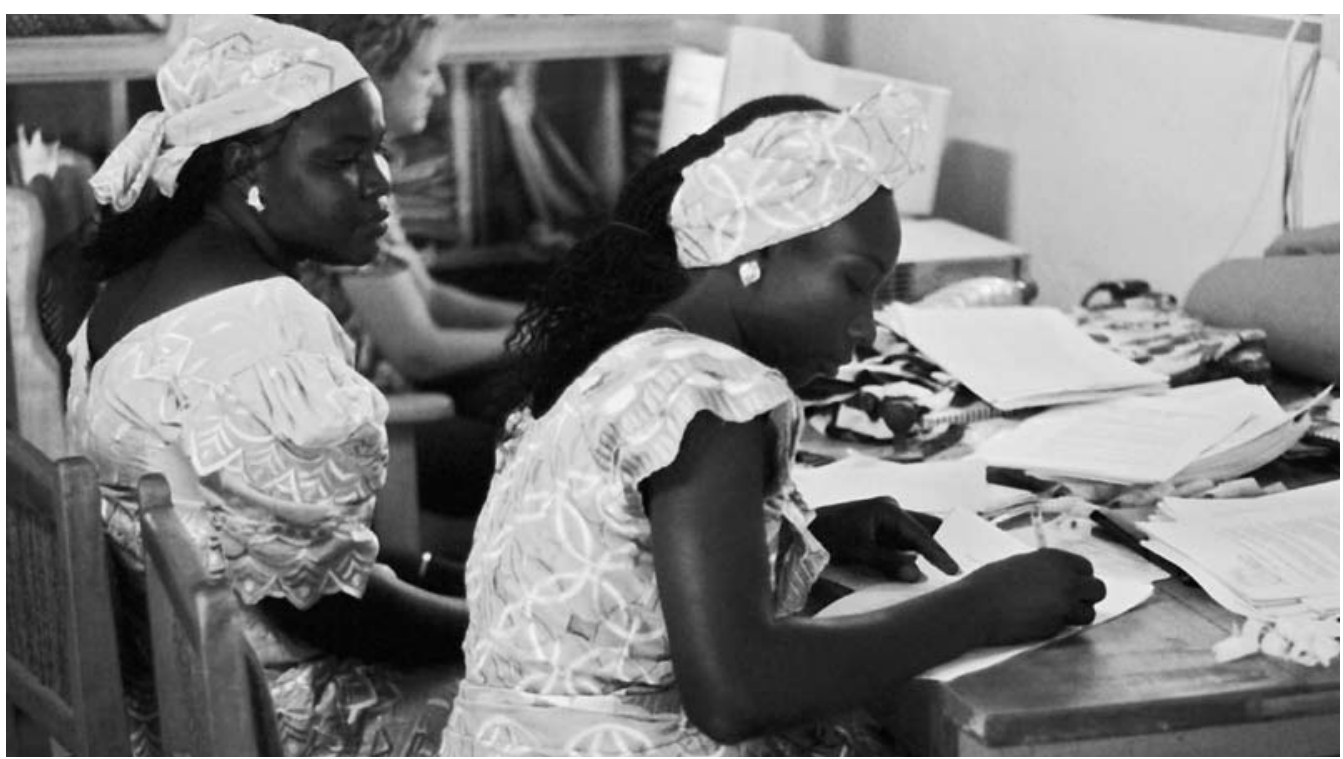

Tabita Damdam (left), herself a survivor of child marriage, encourages parents to support their daughters. She explains that an abandoned daughter "goes looking for food at a man's house" and that the man is "not giving her something to eat for free." 


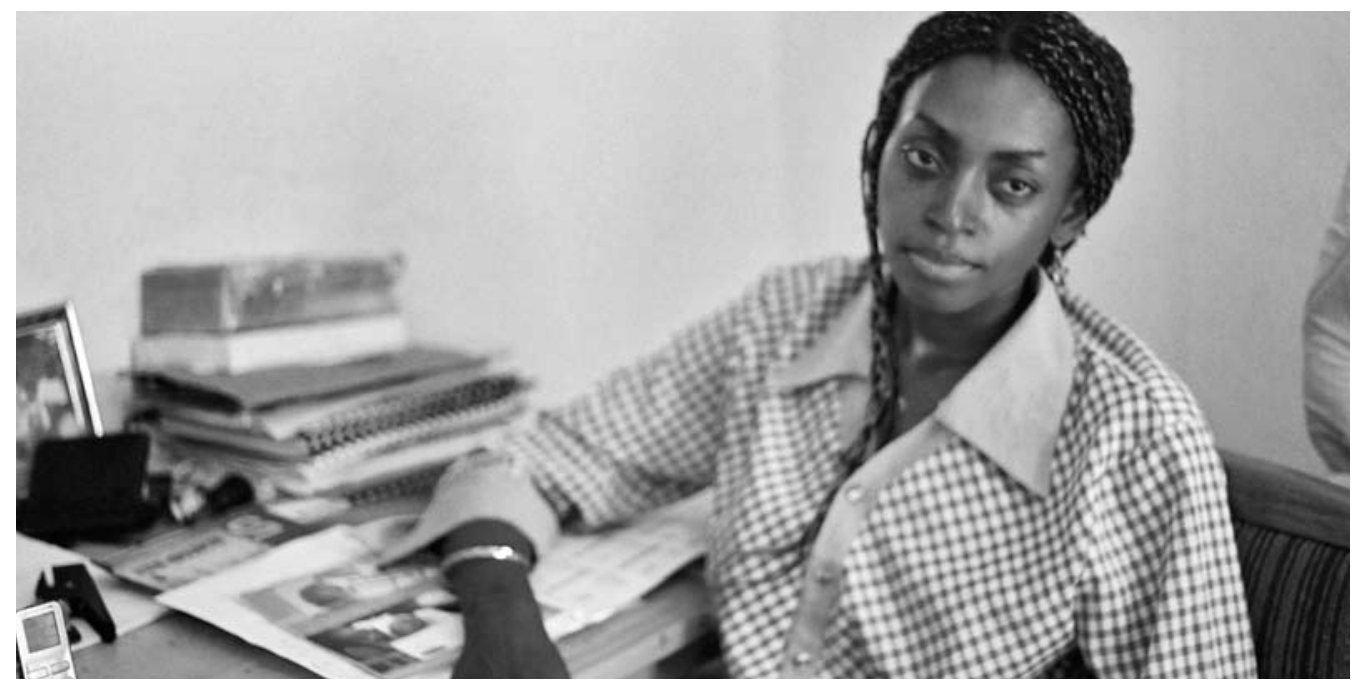

It requires skill to help parents acknowledge the abuse their daughters are suffering because of a forced marriage. For example, Justine Moukouri, a psychologist at the Center, worked repeatedly with the parents of Fatima, a young woman determined to escape an abusive marriage she never wanted (see box below).

\section{Fatima's Story}

Fatima comes from a relatively well-to-do family in Maroua. She was seventeen and in secondary school when she learned from her older brother that her father was intending to send her into marriage. According to her brother, her father's reason was the familiar accusation that "Elle se promenait" — she was "walking around."

Bright and strong-willed, Fatima was devastated to be taken out of school, and dismayed by her father's choice of a husband, a man nearly twice her age. Fatima tried in vain to resist; shortly thereafter, she was forced into marriage and out of school. She refused to have sex with her husband. She ran away repeatedly, seeking refuge with friends and extended family members. Each time, her father found her and brought her back to her husband's home. Nine months into the marriage, a friend told Fatima about the Center for Women's Lives.

Arriving at the Center, Fatima met with Iya and Maimouna, who also suggested she start seeing Justine (the psychologist) on a regular basis. Encouraged by Justine to go back to school, Fatima secretly sold dishes she had received as a wedding gift to pay for school fees. Shortly after she resumed classes, her husband forced her to withdraw from school once again. Justine and the social workers contacted Fatima's father, urg- ing him to let her come home. Although he promised several times to let Fatima return, he did not keep his word. Fatima told Justine that she wanted to run away to live with an older brother, but decided against the plan after Justine expressed concern that the brother would send her back to her father or that Fatima could end up on the street.

One day, Fatima sent Justine a frantic text message. Although Justine was on a day off, she told Fatima to go to the Center and rushed over to meet her. When Fatima arrived, her face and hands were covered with bruises. Justine and the social workers brought her to the hospital to get a medical certificate signed by a physician to document the abuse - evidence that could later be used in court proceedings. After that incident, Fatima's father again agreed to let his daughter come home. He has also promised to bring her request for a divorce to the Lamidat, which regulates marriages sealed by customary (rather than formal) law.

Fatima told me that the staff at the Center for Women's Lives have given her "a lot of courage," and explained that it was they who finally forced her father to listen to her demand for a divorce. "The Center is known here," she said, "because it's something that gives the advantage to women." 


\section{Denouncing Child Marriages Before They Take Place}

Recently, the Center has begun to see a new kind of client: girls seeking to escape forced marriages before they take place or before their husbands force them to have sex. Other concerned citizens are also arriving to denounce such marriages ahead of time. The intervention, in essence, is the same: the client guides the process, and the social workers commit to accompanying her for its duration. First, they go to the girl's home, meet her parents, and explain the probable consequences of child marriage, emphasizing that it is illegal and that girls' rights are protected under Cameroonian law, numerous international agreements, and the Koran. If parents need more convincing, ALVF calls upon its allies in the traditional and religious communities to intervene directly. Usually, the parents back down. But if they refuse, and the girl wants the case pursued, the Association initiates court proceedings.

Siké explains that such cases can also represent opportunities for raising public awareness about child marriage.

In 2007, we had a really extreme case where the authorities had to intervene. It was a nine-year-old girl living in the city with her tutor. Her older brother arranged for her to marry a man back in her village, and he and the mother came to get her. She was the first in her class - a really brilliant girl. Her uncle had heard about us on the radio, and he came here... He said it caused him pain to see that happen to such an intelligent little girl. So we publicized her case on the radio. It was even covered in the papers - we don't mess around!

Everyone was following the story. Germène developed an advocacy and lobbying plan. We set up a meeting with the prefect, who told us that he had followed the case on the radio. And then we sent the dossier to the governor. When he met with us, he said that we should do a big project on child marriage with all of the traditional authorities. That means he's on board with what we are doing.

\section{The Empowerment Program}

Helping women and girls to improve their lives involves addressing more than whatever practical need brings them to the Center. Accordingly, the staff also developed a comprehensive program that seeks to empower survivors of forced and early marriage to break out of their cycle of dependence. The program builds girls' knowledge, skills, and confidence in five main areas:

\section{Legall Empowerment}

Starting with the social worker's initial interview, girls and their families receive a thorough orientation about girls' rights, drawn from regional and international agreements, sacred texts, and Cameroonian laws. Clients and their parents are encouraged to attend regular information sessions and open-door days on girls' rights and human rights. The literacy classes also integrate information on girls' rights. For example, vocabulary lessons include basic legal terms and concepts, and grammatical examples often involve women seeking justice.

\section{Personall Empowerment}

Most of the girls who come to the Center have not been able to complete (or, in some cases, initiate) their schooling; few understand French and many cannot read and write in any language. As a result, their ability to negotiate the social world is severely limited. The French and literacy classes (held at both the Maroua and the Kousséri centers) thus offer girls both a valuable skill and a source of self-esteem. Although the classes can be challenging, the ability to read even simple street signs in French gives the students a burst of confidence. The classes also integrate basic vocabulary on reproductive health and contraception, helping to reinforce the work of the social workers, who educate clients about sexual and reproductive health issues, including HIV and AIDS. Aïssa and Germène, who completed a sexuality education training course in 2005, are currently developing a more comprehensive sexuality education curriculum. 


\section{Sociall Empowerment}

The girls and women who arrive on the Center's doorstep are often experiencing profound social isolation. As is true around the world, married girls often face exclusion both from spaces reserved for unmarried adolescent girls and from spaces for adult wives and mothers. The classes and other group activities at the Center provide girls with valued social support. In addition, a group of survivors of child marriage and young mothers have founded a spin-off group called the Association for the Promotion of the Autonomy and Rights of Girls, ${ }^{11}$ in order to provide a space for girls to socialize, support each other, and find collective solutions to their practical needs.

After some ups and downs, the girls' organization has secured a physical space of its own, and in 2006 obtained support from CARE to provide HIV education and testing. Its first expenditure was to acquire HIV tests, and next to accompany 57 girls to get tested, following up with counseling about prevention or treatment. An estimated five to seven percent of the Center's clients are HIV-positive, and almost all clients are at high risk of HIV infection. Although most girls have heard of the disease, few know how to protect themselves, and fewer still have the means to put that knowledge into practice. The social support and solidarity among the girls helps build their confidence, and HIV-positive members are accepted and encouraged by their peers.

The long-term vision at the Association for the Struggle Against Violence Against Women is for the young members of the spin-off group to become autonomous leaders in their communities. Indeed, Tabita Damdam, one of the group's founding members, grew from a shy girl into a confident and persuasive advocate for women's rights. For most of the girls who join, however, just breaking the cycle of violence and dependence on men remains a formidable, lifelong challenge.

\footnotetext{
${ }^{11}$ In French, L'Association pour la Promotion de l'Autonomie et les Droits de la Fille.
}

\section{Politicall Empowerment}

The Center urges all clients to obtain national identity cards, and staff have trained members of the Association for the Promotion of the Autonomy and Rights of Girls to guide girls throughout the process. So far, they have helped over 500 girls obtain cards, 300 in 2006 alone. The girls' association also conducts its own information sessions on citizenship, democratic participation, evaluating a candidate's platform, and voting.

Tabita Damdam, one of the group's founding members, grew from a shy girl into a confident and persuasive advocate for women's rights.

\section{Economic Empowerment}

Clients' ability to gain control over their sexual and reproductive lives is closely linked to their achieving a degree of economic independence. Without a means to support themselves and their children, girls have neither the confidence nor the leverage to insist on condom use, leaving them vulnerable to HIV and to repeat unwanted pregnancies. In response to this situation, the Association has sought to initiate an income-generation project. As Siké explains:

Income-generating activities give you the power to make a decision. You can say, I don't want to have a lot of children, and I'm making a decision. I don't want to have sex with you because I have the means to feed myself and pay my expenses, and if I have sex with you, I have a condom. And if you refuse to wear it, there won't be any sex.

Making the income-generation project work has been a continual challenge in the face of the girls' immediate and overwhelming practical needs. At the urging of an external evaluator, the Association has decided to scale back the original project. Nonetheless, ALVF continues to promote small-scale enterprises and Center staff train women and girls in financial literacy. 


\section{Lobbying and Advocacy}

Northern Cameroon presents a complex landscape of overlapping governance systems - traditional, religious, and formalpolitical. The Association targets its advocacy at all of these levels.

\section{Working with Traditional and Religious Leaders}

Building alliances in the traditional and religious community has been among the most daunting goals. As Siké points out, however, resistance can also be an indication of success:

They are the guardians of tradition, and they understand that their power is partly based on power and control over women. They really get what we're trying to do . . . they understand that the struggle is at the level of tradition now. And that's what pleases me. Because it's the root: it's the origin, in fact, of the practice. And that means we're at the root.

As the symbolic gatekeepers of their communities, traditional leaders can be critical partners in the struggle against forced and early marriage. From the begin-

"If you see that what you're doing

is going to cause pain and illness

to a human being ... and you

do it anyway, there will be

consequences."

- Hamadou Bachirou,

third-degree chief and ALVF supporter

ning, ALVF's strategy has been to build alliances with the more progressive actors in the traditional and religious communities, in the hope of reaching their conservative peers by extension. They organize trainings starting with less controversial topics such as girls' education; after the training, they follow up with those individuals who stand out as potential allies.

Hamadou Bachirou, a third-degree chief from Maroua's Zurumbaiou neighborhood, has been a dedicated ally for nearly a decade. Bachirou, who first met Siké and Aïssa in 1998 when they organized a community discussion on girls' education in his neighborhood, sees himself as a development actor, a source of knowledge for his community, and a custodian of positive cultural traditions. He explains:

Certain traditions are very positive. We have to support African traditions, and even inculcate them in our children, because if not, we'll lose them. But I don't agree with some other traditions that we've acquired, that were passed down by our great grandparents for example, the practice of marrying women very early. The Muslim religion doesn't say we should do it, and even though the Cameroonian Civil Code isn't very clear about it, I think it's not good, because according to many health professionals, it can really cause problems for the woman. If you see that what you're doing is going to cause pain and illness to a human being, if you reflect on the fact that she's a human being just like you, and you do it anyway, there will be consequences afterwards. I think it's clear: Even religion tells us that human beings are beings who should be respected, whose dignity should be respected.

In his advocacy for the rights of women and girls within his community and among his peers, Bachirou stresses the Koranic basis for his views, particularly the Prophet Mohammed's emphasis on the importance of knowledge for all people - including women. Still, in a system that values respect for age and authority above all, Bachirou often encounters resistance from the elders in his community, as well as his more conservative peers. 
Working with Women in

\section{Political Parties}

On the issue of women's political empowerment, the Association works at two levels: educating Center clients on voting and citizenship, and engaging directly with women in political parties. Political engagement is a key element of the Association's long-term strategy for social change. Women's political representation in Cameroon - and particularly in the far north - is exceptionally low. A 2005 study undertaken by the Association found that in the 2002 elections, only five percent of candidates nominated for any public office were women. Among 29 federal deputies, only one was a woman, and among 45 mayors, not a single woman could be found.

Most of the women who work within political party structures play administrative or supportive roles. Several years ago, Siké and Aïssa set out to identify these women and engage them in various educational activities. They organized trainings on feminism, gender, leadership, human rights, local governance, and lobbying and advocacy, encouraging the women to run for local government posts and to make common cause with women from other political parties on issues affecting women.

ALVF also facilitated a multi-party working group that in 2007 released Electoral Platform of the Women of the Far North. This document identifies four priority areas of concern for women from all political parties: addressing violence against women (especially child marriage and female genital mutilation), increasing women's education and training, increasing women's participation in decision-making and governance, and addressing women's poverty. Validated by 57 women, the Platform represents the ability of the Far North's female public officials to come together across ideological and partisan differences and create, in the words of one participant, "the party of women."

\section{Building Capacities, Forming} Networks

The Far North branch of ALVF also works with a broad range of civil society organizations and local authorities to build their advocacy capacity and encourage them to form issue-based advocacy networks. In 2005, two such networks were created at the provincial level. The first brought together traditional and religious leaders from Maroua and Logone et Chari (the department in which Kousséri is located) who wanted to help eradicate child marriage. The second focused on girls' rights, engaging representatives of NGOs working with

ALVF brought together a diverse

group of $\mathbf{5 7}$ female public officials

to develop a platform and what

one called "the party of women."

women and youth from both Maroua and Kousséri. Coordination among network members remains challenging, however, so these networks have been slow to act.

\section{Working Within the Education System}

The Far North branch of ALVF continues to deepen and expand as it grows. A new project (launched with support from ActionAid Cameroon and buy-in from the provincial governor) involves the formation of community-based brigades to denounce child marriage in four departments of the province. Each brigade consists of one teacher, one traditional leader, two religious leaders (one Christian and one Muslim), one local authority, one parent, and one student. The Association provides training to brigade members and is helping them organize girls' clubs within schools, aimed at reporting a girl's disappearance from school. The brigades can then follow up with the families of girls headed for forced and early marriage to ensure that these girls return to school. 


\section{Ongoing Challenges}

Despite its remarkable success raising awareness about forced and early marriage and assisting the victims of this practice, the Far-North branch of the Association for the Struggle Against Violence Against Women continues to face a number of daunting challenges.

\section{Lack of Politicall Will}

Although child marriage is technically illegal in Cameroon, the Association is operating in a largely unfavorable legal framework. As mentioned earlier, the marriage law itself discriminates against girls (the legal age of marriage is 18 for men and 15 for women). Moreover, the National Assembly has yet to pass a law against violence against women, and Cameroon has yet to ratify the Protocol to the African Charter on Human and People's Rights on the Rights

As Damdam explains, by far the greatest challenge the Center staff face is ensuring that their clients continue to apply what they have learned in a sustainable way.

of Women, which contains strong, detailed language on child marriage (and which ALVF helped write).

Even the favorable conventions that Cameroon has ratified (such as the Convention on the Rights of the Child, the Convention on the Elimination of All Forms of Discrimination against Women (CEDAW), and the African Charter on Human and People's Rights) have yet to be incorporated into the national constitution, which makes it difficult for even the most sympathetic magistrates to apply them in court. In short, although government agencies now regularly refer clients to the Center, Cameroon's policy-making bodies have thus far failed to take responsibility for enacting legal changes that could have more farreaching structural impact.

\section{Staffing and Fundraising Challenges}

Siké herself has always been a major force behind the work of ALVF and the Center - in terms of her strategic and analytical capacities, her gift for networking and relationship-building, and her sheer dedication to the mission and vision. Her intention from the beginning, however, has been to build a sustainable organization that can survive in her absence. To this end, she has worked to mentor Aïssa and Germène, and to ensure that the Center for Women's Lives is equipped to run smoothly in her (frequent) absence. Staff members continue to highlight the need for further training, orientation, and professional development, particularly for new hires.

Likewise, Sikés vision is for the Far North branch eventually to become financially self-sustainable. The Association has been lucky to benefit from the support of a small but strong group of donors. Nonetheless, in a "results-based" funding environment, many donors are wary of funding work on strategic interests, since such work often represents a long-term investment that rarely yields immediate results.

\section{Language Barriers}

Working in Francophone Africa, the Far North branch has limited access to the wide array of English-language resources and networks that could support and extend its work, and limited contact with groups doing similar work in other countries. Even within Cameroon, working in Maroua presents an additional layer of linguistic barriers. Since only 10 percent of the Center's clients speak French, fluency in Fulfulde is a near necessity; finding qualified professionals who also speak Fulfulde, however, can be a daunting task. 
(The nearest university is over 200 miles away in Ngaounderé.) Justine, the psychologist, does not speak Fulfulde, so the social workers have to serve as interpreters during her sessions with non-French speaking clients, complicating the establishment of an ideal therapeutic relationship.

At the same time, communicating in Fulfulde presents its own challenges. For instance, there is no word in Fulfulde for "rights." Lacking a term affirming a positive notion of rights, the staff fall back on explaining the concept in terms of rights violations, which they translate as "sins." Terminological difficulties thus serve to render even more elusive what is already a fairly challenging concept for the girls.

\section{Sustaining Individuall Change}

By far, the greatest challenge the Center staff face is ensuring that their clients continue to apply what they have learned in a sustainable way. During the two weeks I spent in Maroua, staff repeatedly referred to girls' difficulty following their choices through to the end (la difficulté d'aller au bout de leurs choix.) As Siké points out, without a structure to resolve clients' multiple, overlapping, and practical needs on an ongoing basis, only a fraction of the girls who are suffering the consequences of forced and early marriage can empower themselves to break out of the cycle of violence and dependence in the long run. Tabita Damdam explains:

They're not stable. They might show up today, but then they disappear. Since they haven't been to school, they don't have any means. You have to be taught to understand that if you really commit to something, it will eventually provide something in return. But waiting, being patient, it's not easy. So they prefer what seems like the easier route: follow a man, and after a little while, he leaves you, and you start again from zero.

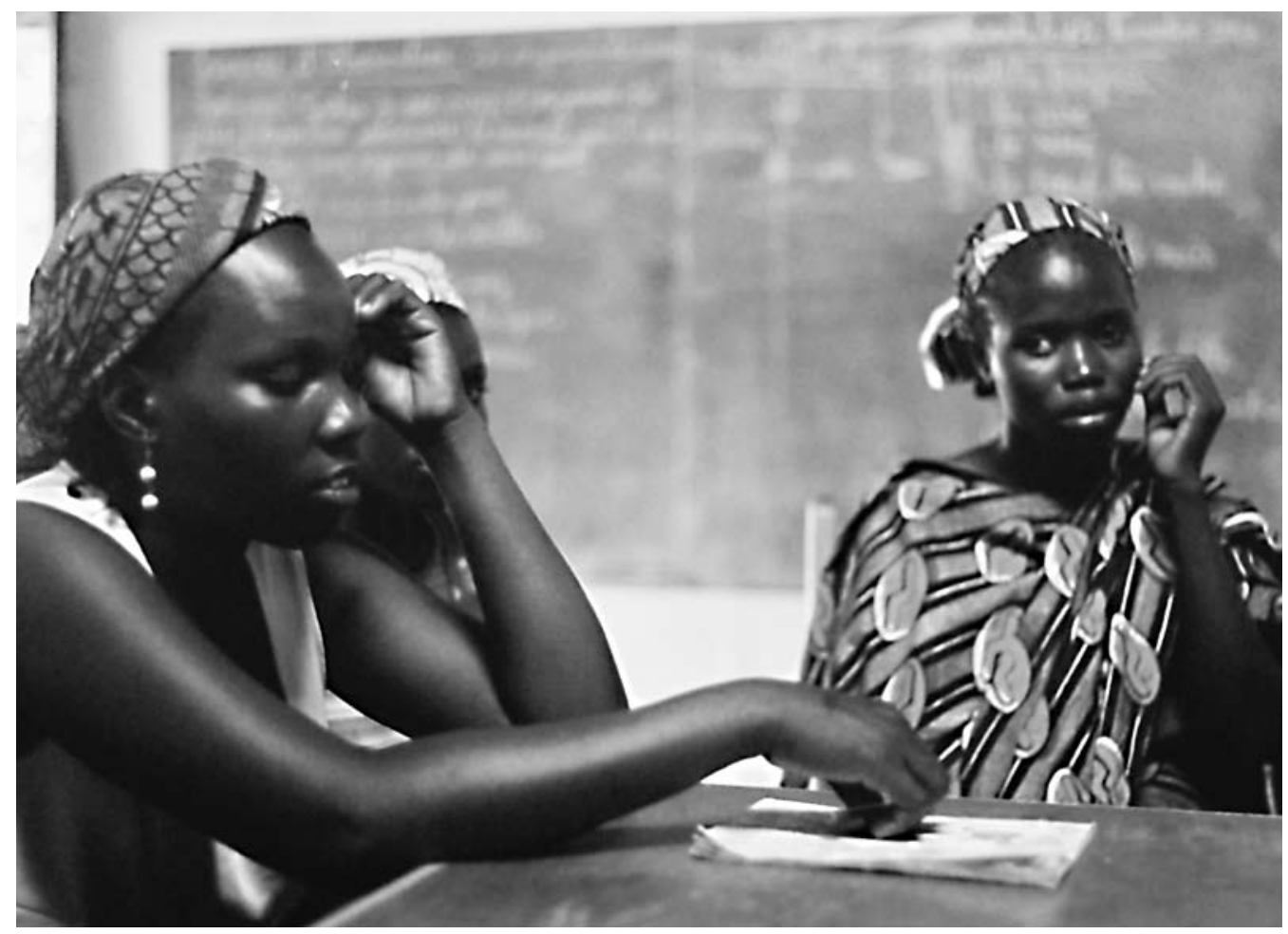

Only about 10 percent of the clients speak French, and not all of the staff speak Fulfulde. Communicating in Fulfulde can also be a challenge; for instance, there is no word in Fulfulde for "rights." 
The social and economic pressure on women to remarry is enormous, and girls like Damdam - who successfully resisted pressure from her parents to remarry, and who is determined to stay single until she finds a husband who will respect her rights - are in the minority. "The social environment is incredibly powerful, and even when the girls have an idea of what they want, they have a lot of obstacles in front of them," explains Germène. Of the six new clients registered at the Kousséri Center between January and March of 2007, for example, none could read, write, or speak French; none had national identity cards, birth certificates, or marriage certificates; none had an income; and none had ever used contra-

Instead of sending menacing notes, the Lamidat now sends clients to the Center. And child marriage, once shrouded in silence, has become a subject of public debate.

ception. Even those girls who are anxious to attend the Center's information sessions are often deterred by transportation costs and by their ambivalence about dedicating time and energy to an activity that will not immediately satisfy their practical needs.

Efforts to optimize girls' long-term independence have also been hampered by the challenges of implementing the income-generation program. Many of the girls have rarely even had the opportunity to handle cash and may lack the basic arithmetic skills to manage even small-scale transactions. More fundamentally, few girls have the luxury to invest time, patience, and capital in anything beyond daily survival. A woman who is given a small amount of money to start a micro-enterprise may decide that it makes more sense to spend that money on food or medical care for her sick, hungry children, leaving her with no capital to invest. As Damdam puts it, "Income generating strategies are for someone who can wait."

\section{Conclusion}

It is still far too early to observe populationlevel impact in the Association's work in the far north. The women seen at the Center represent only a fraction of the women who are affected by the practice of forced and early marriage in northern Cameroon. Nevertheless, the far-north branch has made tremendous gains since the Rotary Club dinner in 1996. More women visit the Center every year; child marriage denunciations are on the rise; hundreds of girls now have national identity cards and are able to vote; many others have learned to read, write, and speak French; many women have secured marriage certificates that solidify their rights in marriage (and may prevent them from being thrown out by their husbands for opposing their daughters' forced marriages); and a handful have begun to practice contraception.

The Far-North branch counts on a growing group of allies in civil society, the state, and traditional governance structures, and the organization - which is explicitly feminist - is widely known and highly regarded. Although many of the women and girls who have come to the Center are still struggling to turn their lives around, some girls do manage to break the cycle, and many others have been able to negotiate better terms for their existing relationships. A few - like Tabita Damdam - have emerged as powerful agents for change. Even the Lamidat, which once slipped menacing notes under the door, now refers its toughest cases to the Center.

As a result of the Association's efforts, the practice of child marriage, once shrouded in silence, is now a subject of public and political debate. "The greatest success we've had is that people are talking about this practice, it's become a public debate; before people didn't dare to talk about it," Aïssa explains. Even the language people use has changed as a result of ALVF's influence. "Women in politics, today they say, 'We are political survivors,' " Siké reports. "They use the words 'discrimination' and 
'violence' — and that's a victory. Even men use the term 'violence' now."

There is a saying in Cameroon that "On ne dérancine pas un arbre en quelques coups de hâche," which loosely translates as "A few chops from an axe won't uproot a tree." The practice of child marriage has deep social, economic, and cultural roots. "I've realized that we can't end forced and early marriage with the law alone," says Aïssa. "The law is not enough, you need a lot of awareness, and you need to change people's minds. You need to change the val- ues and the culture." That process will take a long time, but in the interim, the Center will continue to welcome girls and women who are beginning to realize, like Aïssa and countless others realized, that what they are being put through is not right.

"This work, it's a vocation," says Maimouna. "You sleep with the girls' problems in your head, you think about how to help her resolve her situation - she could try this, she could try that. We have a lot of pride in what we do. Me, personally, if I manage to help one woman now, I'm proud."

\section{Lessons Learned}

- Concepts of human rights and of feminism can be meaningful and effective in combating child marriage, even in settings where these concepts have previously had little or no cultural currency. While building relationships and networks was critical, ALVF was candid about its perspective, chose a high-profile strategy, and used opportunities for public attention as entry points for wider awareness-raising.

- Keep in mind both women's practical needs and their strategic interests. Helping women in crisis and supporting their own efforts to organize can empower clients, lend the organization public credibility, and help build the local base that is essential to effecting sustainable social change.

- In working with girls who have been abandoned by their husbands or who are fleeing their marriage, organizations need strategies to deal with girls' parents as well as with their husbands.

\section{References}

Adair, Tim. 2007. "HIV status and age at first marriage among women in Cameroon." DHS Working Paper No. 33. Washington, DC: USAID and Macro International.

Doumara, Aïssa and Siké Billé. 2007. "Strategies de lutte contre les marriages précoces et forces dans l'extrême nord du Cameroun." Unpublished.

Institut National de la Statistique (INS) and ORCMacro. 2004. Enquête Démographique et de Santé du Cameroun 2004. Calverton, MD: INS and ORC Macro.
Molyneux, Maxine. 1985. "Mobilization without emancipation? Women's interest, the state, and revolution in Nicaragua." Feminist Studies 11(2): 227-254.

Passage Maroua. 2007. "Manuel de I'acteur en santé genesique." (Based on analysis of Cameroon's 2004 Demographic and Heath Survey, and research conducted by AQUASOU.)

UNESCO. 2009. "Country profile: Cameroon." $<$ http://www.unesco.org/uil/litbase/?menu= 4\&programme=14.> Accessed 28 May 2009. 
El matrimonio en la infancia y el matrimonio forzado de las jóvenes es una violación extensa de los derechos humanos. Tales matrimonios roban a las jóvenes su infancia y la opción de una educación. Frecuentemente esto conduce a relaciones sexuales forzadas, la presión de tener hijos muy pronto, y la violencia doméstica. En muchos entornos, niñas casadas se enfrentan a un mayor riesgo de complicaciones en el embarazo y el parto (incluyendo la fístula obstétrica), así como el VIH. Debido a que son más propensas a casarse con hombres mucho mayores que ellas, también son más propensas a gastar una parte importante de sus vidas viudas, abandonadas o divorciadas - generalmente sin heredar la propiedad y sin la capacidad de ganarse la vida. Sin embargo, esta práctica sigue siendo común en muchas regiones. En el sur de Asia, 48 por ciento de las mujeres de 15 a 24 años se casaron antes de la edad de 18 años; en África, la proporción es de 42 por ciento. Aunque el factor fundamental es el bajo estatus de las mujeres, la desigualdad de género interactúa con la pobreza y varias tradiciones culturales para perpetuar esta práctica.

En la extrema pobreza al norte de Camerún, la Asociación para la Lucha contra la Violencia contra la Mujer (ALVF) aborda el matrimonio en la infancia a través de un programa combinado de servicios y advocacy. Los servicios se basan en el Centro para la Vida de las Mujeres, donde las niñas que han huido (o han sido expulsadas de) este tipo de matrimonios pueden obtener apoyo emocional y orientación, capacitación en lenguaje y alfabetización, y actividades de empoderamiento. Por ejemplo, muchas necesitan ayuda para convencer a un esposo a pagar una pensión alimenticia para sus hijos debido al abandono a ella y a sus hijos. (La edad media del primer matrimonio entre las clientes es de 13-14 años, aunque algunos han sido de tan sólo diez años.) Al ir a reunirse con los maridos, el personal de ALVF Ileva copias del Código Penal y diversos pactos internacionales de derechos humanos ratificados por Camerún, y explican que fue en contra de la ley para cualquier hombre el haberse casado con una niña sin su consentimiento. Personal de ALVF dice que "Al abrir los documentos, [el marido] no lo toma a la ligera; ellas lo explican: 'No es cosa mía, es la ley.'"

La organización aboga públicamente con los padres, lideres tradicionales, y funcionarios electos - contra la práctica del matrimonio en la infancia, así como otros problemas que afectan a las mujeres. Este equilibrio entre las necesidades prácticas inmediatas de las mujeres y sus intereses estratégicos a largo plazo es clave para la visión del programa y de su fundador, Siké Billé.

La rama al Extremo Norte de ALVF tiene sus retos. El Código Penal permite a las niñas a casarse a los 15 años (para los niños es 18 años), y la violencia contra las mujeres no es un delito. También hay retos en contratación de personal y de recaudación de fondos, sobre todo porque ALVF presta una fuerte gama de servicios para ayudar a un pequeño número de mujeres a cambiar sus vidas, en lugar de ofrecer un servicio breve a una gran base de clientes. El mayor obstáculo para el progreso, sin embargo, es sostener el cambio individual; para muchas mujeres, el siguiente paso es aún otro matrimonio abusivo. Sin embargo, junto con potenciar a las mujeres, ALVF ha dado grandes pasos en la creación de un espacio para el debate público sobre el matrimonio en la infancia y el matrimonio forzado. Para una organización abiertamente feminista en una región muy conservadora, esto es realmente un logro. 
Le mariage précoce et forcé des filles représente une violation courante des droits humains. Il vole à la fille son enfance et sa chance d'éducation. II mène souvent aux rapports sexuels forcés, à la pression de maternité précoce et à la violence conjugale. Dans de nombreux contextes, la très jeune mariée court un plus grand risque de complications de la grossesse et de l'accouchement (y compris la fistule obstétricale), ainsi que de contraction du VIH. Parce qu'elle épouse souvent un homme beaucoup plus âgé qu'elle, elle est aussi plus susceptible de passer une bonne partie de sa vie veuve, abandonnée ou divorcée — généralement sans héritage ni capacité de gagner sa vie. La pratique reste pourtant courante dans de nombreuses régions. En Asie du Sud, 48\% des filles de 15-24 ans ont été mariées avant l'âge de 18 ans; en Afrique, la proportion est de $42 \%$. Si la cause profonde principale en est le faible statut de la femme, I'inégalité de genre se mêle à la pauvreté et à diverses traditions culturelles pour perpétuer la pratique des mariages d'enfants.

Dans l'extrême-nord fort pauvre du Cameroun, I'Association de la Lutte contre la Violence faite aux Femmes (ALVF) s'oppose au mariage précoce et forcé à travers un programme combiné de services et de plaidoyer. Les services sont proposés au Centre Vie de Femmes de l'ALVF, où les filles qui ont fui ces mariages (ou qui en ont été répudiées) peuvent bénéficier d'un conseil et soutien affectif, d'un programme d'alphabétisation, d'un appui économique et d'activités d'autonomisation. La cliente type a souvent besoin $d^{\prime}$ aide pour convaincre le mari qui l'a abandonnée ainsi que ses enfants de lui verser de quoi les nourrir. (L'âge moyen au premier mariage des clientes du centre est de 13-14 ans, mais certaines avaient à peine
10 ans.) Lors de la rencontre avec les maris, I'ALVF leur montre un exemplaire du code pénal et des conventions internationales sur les droits humains ratifiées par le Cameroun, leur expliquant qu'il est contraire à la loi d'avoir épousé une fille sans son consentement. Et de décrire la réaction des hommes : "Quand vous ouvrez ces documents, ils ne prennent pas ça à la légère. II suffit de leur dire : «Ce n'est pas moi, c'est la loi. »»

L'organisation plaide publiquement auprès des parents et des dirigeants traditionnels et élus - contre la pratique des mariages d'enfants, ainsi que pour la résolution d'autres problèmes affectant les femmes. L'équilibre entre les besoins pratiques immédiats des femmes et leurs intérêts stratégiques à long terme est fondamental à la vision du programme et de sa fondatrice, Siké Billé.

L'antenne Extrême-Nord de I'ALVF doit faire face à bien des défis. Le code pénal autorise le mariage des filles dès I'âge de 15 ans (18 ans pour les garçons) et la violence à I'encontre des femmes n'est pas criminalisée. Les problèmes de dotation en personnel et de financement sont endémiques, car I'ALVF fournit non pas une simple prestation à un grand nombre de clientes, mais des services en profondeur appelés à aider un petit nombre de femmes seulement. Le plus grand défi n'en est pas moins l'ancrage du changement individuel, car beaucoup de clientes retombent dans les affres d'un nouveau mariage abusif. Outre l'autonomisation des femmes au jour le jour, I'ALVF a néanmoins réalisé de grands progrès vers la création d'un espace de débat public du mariage précoce et forcé. Pour une organisation ouvertement féministe dans une région résolument conservatrice, il s'agit, certes, d'un bel accomplissement. 


\section{About the Authors}

Sajeda Amin is a Senior Associate with the Poverty, Gender, and Youth Program at the Population Council.

Andrea Lynch is a Program Officer at EMpower. She was formerly on the staff of the International Women's Health Coalition.

\section{Acknowledgments}

We wish to thank the staff of ALVF for their cooperation in preparing this edition of $Q / C / Q$, as well as the International Women's Health Coalition for technical support.

We invite your comments on Quality/Calidad/Qualité. If you would like to be included on our mailing list, please send an e-mail to: qcq@popcouncil.org. Most past editions are available online at $<$ www.popcouncil.org/publications/qcq/default.htm $>$. Single or multiple print copies of past editions may be ordered by e-mail.

No. 1 Celebrating Mother and Child on the Fortieth Day: The Sfax Tunisia Postpartum Program, 1989. (E)

No. 2 Man/Hombre/Homme: Meeting Male Reproductive Health Care Needs in Latin America, 1990. $(\mathrm{E}, \mathrm{S})$

No. 3 The Bangladesh Women's Health Coalition, 1991. (E)

No. 4 By and For Women: Involving Women in the Development of Reproductive Health Care Materials, 1992. (E,S)

No. 5 Gente Joven/Young People: A Dialogue on Sexuality with Adolescents in Mexico, 1993. (E,S)

No. 6 The Coletivo: A Feminist Sexuality and Health Collective in Brazil, 1995. (E,P,S)

No. 7 Doing More with Less: The Marie Stopes Clinics of Sierra Leone, 1995. (E)

No. 8 Introducing Sexuality within Family Planning: Three Positive Experiences from Latin America and the Caribbean, 1997. (E,S)

No. 9 Using COPE to Improve Quality of Care: The Experience of the Family Planning Association of Kenya, 1998. (E,S)

No. 10 Alone You Are Nobody, Together We Float: The Manuela Ramos Movement, 2000. (E,S)

No. 11 From Patna to Paris: Providing Safe and Humane Abortion, 2001. (E)

No. 12 Universal Sexuality Education in Mongolia: Educating Today to Protect Tomorrow, 2002. (E)

No. 13 What about Us? Bringing Infertility into Reproductive Health Care, 2002. (E)

No. 14 "My Father Didn't Think This Way": Nigerian Boys Contemplate Gender Equality, 2003. (E,F)

No. 15 Linking Reproductive Health to Social Power: Community Health Workers in Belize and Pakistan, 2004. (E)

No. 16 Healing Wounds, Instilling Hope: The Tanzanian Partnership Against Obstetric Fistula, 2004. $(\mathrm{E}, \mathrm{F}, \mathrm{Sw})$

No. 17 In Our Own Hands: SWAA-Ghana Champions the Female Condom, 2006. (E)

No. 18 Living Up to Their Name: Profamilia Takes on Gender-based Violence, 2006. (E)

No. 19 And How Will You Remember Me, My Child? Redefining Fatherhood in Turkey, 2009. (E)

$(\mathrm{E})=$ English; $(\mathrm{F})=$ French; $(\mathrm{P})=$ Portuguese;

(S) = Spanish; (Sw) = Swahili 
Q/C/Q No. 20

Quality/Calidad/Qualité/ 